\title{
On the discretization of river networks for large scale hydrologic-hydrodynamic models
}

\section{Discretização de redes fluviais para modelos hidrológico-hidrodinâmicos de grande escala}

\author{
Fernando Mainardi Fan ${ }^{1}$ (D), Vinícius Alencar Siqueira ${ }^{1}$ (D), Ayan Santos Fleischmann ${ }^{1}$ (D), João Paulo Fialho Brêda ${ }^{1}$ (D), \\ Rodrigo Cauduro Dias de Paiva ${ }^{1}$ (D), Paulo Rógenes Monteiro Pontes ${ }^{2}$ (D) \& Walter Collischonn ${ }^{1}$ (D) \\ ${ }^{1}$ Universidade Federal do Rio Grande do Sul, Porto Alegre, RS, Brasil \\ ${ }^{2}$ Instituto Tecnológico Vale - Desenvolvimento Sustentável, Belém, PA, Brasil \\ E-mails: fernando.fan@ufrgs.br(FMF), vinisiquera@gmail.com (VAS), ayan.fleischmann@gmail.com (ASF), joaopaulolfb@gmail.com (JPFB), \\ rodrigocdpaiva@gmail.com (RCDP),p.rogenes@gmail.com (PRMP), collischonn@iph.ufrgs.br (WC)
}

\begin{abstract}
The discretization of river networks is a critical step for computing flow routing in hydrological models. However, when it comes to more complex hydrologic-hydrodynamic models, adaptations in the spatial representation of model calculation units are further required to allow cost-effective simulations, especially for large scale applications. The objective of this paper is to assess the impacts of river discretization on simulated discharge, water levels and numerical stability of a catchment-based hydrologic-hydrodynamic model, using a fixed river length $(\Delta \mathrm{x})$ segmentation method. The case study was the Purus river basin, a sub-basin of the Amazon, which covers an area that accounts for rapid response upstream reaches to downstream floodplain rivers. Results indicate that the maximum and minimum discharges are less affected by the adopted $\Delta \mathrm{x}$ (reach-length), whereas water levels are more influenced by this selection. It is showed that for the explicit local inertial one-dimensional routing, $\Delta \mathrm{x}$ and the $\alpha$ parameter of CFL (Courant-Friedrichs-Lewy) condition must be carefully chosen to avoid mass balance errors. Additionally, a simple Froude number-based flow limiter to avoid numerical issues is proposed and tested.
\end{abstract}

Keywords: Hydrological modelling; Hydrodynamic modelling; Spatial discretization; Local inertia; River reach; MGB model.

\section{RESUMO}

A discretização da rede fluvial é uma etapa crítica para o cálculo da propagação de vazões em modelos hidrológicos. No entanto, quando se trata de modelagem hidrológico-hidrodinâmica mais complexa, adaptações na representação espacial das unidades de cálculo do modelo são necessárias para permitir simulações eficientes, especialmente para aplicações em grande escala. O objetivo deste artigo foi avaliar os impactos da discretização dos rios nas vazões simuladas, níveis de água e estabilidade numérica de um modelo hidrológicohidrodinâmico baseado em divisões por sub-bacias, usando um método de segmentação de comprimento do rio $(\Delta \mathrm{x})$ fixo. $\mathrm{O}$ estudo de caso foi a bacia do rio Purus, um afluente do rio Amazonas, que abrange uma área que conta desde regiões de respostas rápidas a montante até rios de várzea a jusante. Os resultados indicam que as descargas máximas e mínimas são menos afetadas pelo $\Delta \mathrm{x}$ adotado, enquanto os níveis de água são mais influenciados por essa seleção. Mostra-se que, para a propagação unidimensional inercial local usando um modelo explícito, o $\Delta \mathrm{x}$ e o alfa da condição CFL (Courant-Friedrichs-Lewy) devem ser cuidadosamente escolhidos para evitar erros de balanço de massa. Além disso, um limitador de fluxo baseado em número Froude simples é proposto e testado.

Palavras-chave: Modelagem hidrológica; Modelagem hidrodinâmica; Discretização espacial; Método inercial local; Trecho de rio; Modelo MGB. 


\section{INTRODUCTION}

Hydrological models are a set of mathematical equations designed to represent components of the hydrological cycle, allowing for the understanding of its processes and many other applications, for instance, the assessment of land use and climate change impacts (Sorribas et al., 2016; Bravo et al., 2014; Nóbrega et al., 2011) or operational flood and drought forecasting (Alfieri et al., 2013; Sheffield et al., 2014; Fan et al., 2015). These models usually account for a water budget (rainfall storage and runoff) module and a water flow along river networks (i.e. routing) module.

At larger scales, rivers typically cross several hundreds of kilometers with different climatic and geophysical conditions, encompassing well-defined channels in mountainous regions to extensive floodable areas at lowlands. While simplified physical approaches are known to be suitable for flow routing in steep terrains (Price, 2018), and yet adopted by most of current global hydrological models (Bierkens, 2015; Kauffeldt et al., 2016), complexities emerging from river-floodplain water exchange in mild slopes can lead to flood peak delay and backwater effects on tributaries, which cannot be resolved with simple flow routing methods (Trigg et al., 2009; Yamazaki et al., 2011; Paiva et al., 2011; Fleischmann et al., 2016; Lopes et al., 2018; Zhao et al., 2017). In contrast, hydraulic models are able to represent floodplain and backwater processes at some computational cost and with large data requirements (Chaudhari et al., 2019). Modeling large scale river hydrodynamics can be very challenging, since many of the world largest floodplains occur in ungauged or poorly monitored areas, such as the Amazon, Congo, Niger and Paraguay rivers (Paz et al., 2011; Pedinotti et al., 2012; Paiva et al., 2013; Tshimanga \& Hughes, 2014).

Over the last few decades, significant progress in remote sensing technologies has introduced new perspectives for hydrodynamic modeling studies (Schumann et al., 2009; Yan et al., 2015; Sampson et al., 2016; Sheffield et al., 2018; Bates et al., 2018). The near-global coverage of Shuttle Radar Topography Mission - SRTM (Farr et al., 2007) led to the development of global, voidfilled Digital Elevation Models (DEM) (e.g., Jarvis et al., 2008) and derivatives such as the one developed by the HydroSHEDS project (Lehner et al., 2006), which have the advantage of being open access for the scientific community. Together with the huge amount of information brought by remotely sensed data, increasing advances in computational resources have encouraged the application of large-scale hydrodynamic models in many regions of the globe. In this context, the offline coupling between a hydrological and a fully $2 \mathrm{D}$ or $1 \mathrm{D} / 2 \mathrm{D}$ channel/floodplain hydraulic model has proven a very promising approach to simulate floodplain dynamics in complex river systems (Biancamaria et al., 2009; Paz et al., 2011, 2014; Schumann et al., 2013; Hoch et al., 2017; Munar et al., 2018). However, 2D flood inundation models are still computationally expensive depending on the modeling objectives and are strongly sensitive to DEM accuracy. The latter is important because high quality terrain datasets (e.g., LiDAR or TanDEM-X) with global coverage are not freely available to the general public (Yan et al., 2015; Sampson et al., 2016; Archer et al., 2018). This particular problem can be even more pronounced in densely vegetated areas such as the Amazon Basin, since the C-band radar of the widely used SRTM is not able to fully penetrate the vegetation canopy
(Carabajal \& Harding, 2005; Berry et al., 2007; O’Loughlin et al., 2016; Yamazaki et al., 2017).

A simpler approach used by some large-scale hydrodynamic studies is to adopt one-dimensional flow routing treating the floodplains as storage units (Yamazaki et al., 2011; Paiva et al., 2011). Notwithstanding the limitations of the $1 \mathrm{D}$ model structure, especially its inability to represent water movement in multiple directions, several researches have demonstrated its potential at regional to global scales with satisfactory results (Yamazaki et al., 2014; Ikeuchi et al., 2015; Mateo et al., 2017; Pontes et al., 2017; Zhao et al., 2017; Lopes et al., 2018; Siqueira et al., 2018). Moreover, a key improvement of recent studies, albeit initially proposed for 2D flood inundation modeling, is the use of the explicit local inertia approximation of the shallow water equations (Bates et al., 2010), which has been an interesting alternative to the full Saint-Venant hydrodynamic equations due to its relative efficiency and easier implementation. The ability to speed up model computations together with code parallelization (Yamazaki et al., 2013) can be crucial either for handling finer model resolutions or when several model runs are made necessary, for instance, for uncertainty assessment in ensemble flood forecasting (e.g., Pappenberger et al., 2005), data assimilation (e.g., Brêda et al., 2017) or parameter estimation (e.g., Dung et al., 2011).

Another key issue for large-scale river routing is to define how the river network is depicted within the model. Partitioning a basin in a regular latitude-longitude cell grid, thus providing a gridded-based network river map, is a very common practice since coupling groundwater, atmospheric and land surface models (LSM) can be easily done with a simple cell-by-cell relationship (e.g., Decharme et al., 2008). Conversely, large errors in length and slope of rivers, as well as the definition of flow directions over coarse resolution maps, must be treated using upscaling techniques (e.g., Paz et al., 2006; Paz \& Collischonn, 2007; Yamazaki et al., 2009; Wu et al., 2011), while a realistic representation of channels and floodplains can be only achieved with a very fine grid cell resolution (Goteti et al., 2008; Lehner \& Grill, 2013).

A basin can also be divided in several unit-catchments according to its underlying DEM (e.g., Beighley et al., 2009; David et al., 2011; Paiva et al., 2011, 2013; Luo et al., 2017; Siqueira et al., 2018) to preserve small-scale topographic features. This approach seems to be more suitable for hydrological models since topography strongly controls surface water storage and movement (Goteti et al., 2008), and a better connectivity of the river system can be ensured by the generation of high-resolution, vector-based network river maps (David et al., 2013; Paiva et al., 2011; Yamazaki et al., 2013; Lin et al., 2018).

Discussions regarding the choice of grid or vector-based discretizations are present in recent literature. There is a strong motivation towards the use of the latter approach especially for large-scale modeling, since: (i) it is possible to reduce computational demand due to the more flexible computational elements (Beighley et al., 2009; Lehner \& Grill, 2013; Yamazaki et al., 2013); (ii) there is a smaller sensitivity of model parameters to its spatial resolution, which can improve model scalability because it respects topography properties (Tesfa et al., 2014); (iii) gaugeto-reach association becomes easier with a high resolution river network, giving rise to higher societal meaning (David et al., 
2013), when water users can easily identify known features in the simulation, such as a known river segment in the hydrographic map; and (iv) it is more suitable for hydro-ecological applications that typically require river-reach scale resolution (Lehner \& Grill, 2013). Because of these benefits, some river routing models have been implementing vector-based river maps for computations over continental domains, such as RAPID (Tavakoly et al., 2016) and mizuRoute (Mizukami et al., 2016), as well as for global scale simulations, as in HydroROUT (Lehner \& Grill, 2013). More hydrologically consistent DEMs are also becoming popular for hydrological-hydrodynamic models applications in recent works (Yamazaki et al., 2019).

These advances in regional to global hydrologic and 1D hydrodynamic modeling studies come with a need of better understanding how choices in parameters and model structures affect the simulation results. Although the impact of cross-section geometry and channel roughness in variables such as flood extent and river water levels has already been addressed by some previous studies (e.g. Yamazaki et al., 2011; Paiva et al., 2013; Saleh et al., 2013; Luo et al., 2017; Pontes et al., 2017), there is a lack of literature when it comes to river network discretization in the context of modeling at large scales. In a recent work, Mateo et al. (2017) assessed the effect of varying spatial resolution and flow connectivity using a global river model (CaMa-Flood) in the Chao Phraya River basin $\left(158,000 \mathrm{~km}^{2}\right)$. It was found that model predictions in very flat floodplains and deltas can benefit from finer spatial resolutions if multiple downstream connectivity is accounted for in model structure, while using single downstream connectivity not necessarily implies in better results when resolution is improved. On the other hand, to the authors knowledge, large scale evaluations regarding 1D model stability conditions (i.e., mass balance numerical issues) were not previously addressed, which is of importance as 1D hydrodynamic studies encompassing entire basins have been adopting criteria from 2D modeling that are known to be suitable for flat regions (e.g. Yamazaki et al., 2013; Pontes et al., 2017).

In the present work we explore the knowledge gap regarding the river network discretization for large scale hydrologichydrodynamic models, focusing on vector-based representation of drainage networks. Our driving questions are: what is the effect of the spatial discretization on the distribution of unit-catchments, and on simulated river discharge and water levels? What is the effect of spatial discretization on modeling numerical aspects?

\section{METHODOLOGY}

In this study, we used a vector-based, spatial discretization method that assumes unit-catchments with fixed river lengths. This method is interesting because it allows a better control of the total computational time of the hydrodynamic model, as discussed in the following text.

For the hydrologic-hydrodynamic simulation we used the MGB model (Modelo de Grandes Bacias in portuguese; Pontes et al., 2017) to assess impacts of catchment / river discretization on simulations, using the Purus river basin (an Amazon tributary) as a case study. The following sections provide a detailed description of the discretization method, the model, the study area, the input data and the performed assessments.

\section{A length-delimited, vector-based river discretization for hydrologic-hydrodynamic modeling}

An initial step needed to run a hydrological or a river routing model is to derive flow directions from the terrain data. For large-scale applications the most widely used approach is the deterministic eight-node (D8) method, where the direction that the water flows in a given pixel is assigned as a single direction towards the steepest slope among its eight surrounding neighbors (Jenson \& Domingue, 1988). Although other approaches were proposed to account for multiple directions and better represent the water movement over terrain (Tarboton, 1997; Seibert \& McGlynn, 2007), they can create diffuse and overlapping catchment area boundaries (Jones, 2002).

A pit removal procedure is often applied prior to flow direction in order to produce a "hydrologically corrected" (or conditioned) DEM, since the existence of flat regions or single topographical depressions leads to areas without a defined outlet and disconnected drainage patterns (Martz \& Garbrecht, 1999; Planchon \& Darboux, 2001; Wang \& Liu, 2006; Buarque et al., 2009). Currently, global datasets of flow directions with extensive manual corrections are available at different spatial resolutions (e.g., Lehner et al., 2008), which can be suitable for many large scale hydrological and river routing modeling applications.

The sum of pixels along flow direction paths leads to a flow accumulation matrix, which needs to be reclassified in order to define the main channels. However, depending on the model domain, it is recommended to propagate the upstream area along the flow directions instead of the upstream number of pixels, in order to properly consider the area of the pixels, which can vary at different latitudes if the pixels have the same resolution in angular units, when using geographical coordinates (Paz \& Collischonn, 2007). Drainage networks are then extracted by means of reclassification of the flow accumulation matrix using a constant area threshold, corresponding to the smallest area at which channel hydrodynamics is represented. Further discussions regarding the choices of area thresholds for river networks definitions, and even suggestions for the use of variable thresholds, can be found in Fan et al. (2013).

One of the common procedures to derive unit-catchments is to use well-known GIS packages, as an example, the ArcHydro definitions (Paiva et al., 2011; Yamazaki et al., 2013). Similar procedures are also used in free softwares such as QGIS (e.g., the GRASS GIS plugin). In this method, all pixels that are draining to a given river reach belong to the same unit-catchment, while a reach is defined by a river segment between two junctions or between a river spring and its downstream junction. Although the method provides a simple and logical description for the model topology, it produces high variability of reach lengths that are not suitable to more complex hydraulic modeling procedures. Paiva et al. (2011) addressed this problem assuming unit-catchments as floodplain units and dividing reaches according to a predefined maximum length, when using a full 1D Saint-Venant hydrodynamic model. For handling short and long reaches in a global inertial routing modelling, Yamazaki et al. (2013) adopted outlet rejection and outlet adding procedures according to minimum and maximum length thresholds, the latter equal to double the minimum threshold value. 
In the present study, we adopted a fixed-length vector river discretization in order to provide equal flow distances and to enhance model time-step and runtime control, as well as to facilitate the coupling between hydrological and hydrodynamic modules. This discretization method is the same used by Siqueira et al. (2018) for continental hydrologic-hydrodynamic modeling in South America. The discretization procedure adopted is described below.

\section{Step 1 - Marking outlets}

Starting from a previously delineated river network from usual definitions (Buarque et al., 2009), the initial step is to mark all the intermediate outlets corresponding to the very downstream point of a given river reach (orange boxes in Figure 1a). For that, the algorithm first identifies the river junctions by checking if two or more neighboring pixels of the D8 flow direction grid are over the river network and also drain to the analyzed pixel. In a positive case, the grid positions (row, column) of nearby upstream draining pixels (i.e., the intermediate outlets) and their respective flow accumulated areas are both stored in a vector. This procedure is repeated for each junction until the entire grid is evaluated and all the intermediate outlets are found. In addition, the attributes of the pixel with the largest upstream area (basin outlet) are also included in the vector of intermediate outlets, as it is not connected to any junction.

Step 2 - Delineating reaches and unit-catchments by a length threshold

The next step is to segment streams by using a predefined reach length (threshold) and a stepwise approach. The algorithm begins at the basin outlet and performs the segmentation in the upstream direction (Figure 1b), so that the vector of intermediate outlets is sorted descending in terms of drainage area. After setting an accumulated length value of zero to the basin outlet (green square in Figure 1b), the algorithm starts tracing in the upstream direction and the accumulated length is updated at each pixel using the Distance Transforms method (Butt \& Maragos, 1998) to improve distance calculations (Paz \& Collischonn, 2007). Whenever the length threshold is exceeded, as indicated by the break lines in Figure 1b, the accumulated length is reset to zero and a unique number (ID) is assigned to all pixels belonging to the same river reach. It is worth noting that the algorithm selects the upstream pixel with the largest accumulated area (blue squares in Figure 1b) to keep tracing when a junction is found along the flow path. Moreover, if the length threshold is not met at the very upstream (headwater) pixel, the river network at this point is further extended following the pixel with the largest drainage area (dashed line in Figure 1b). It is important to note that the length can be smaller than the predefined value since it is topographically limited by headwater unit-catchment boundaries. Moreover, the extension of the river reach in the most upstream unit-catchment can impact the river length in the headwater areas (where there exist high uncertainties in drainage network definition), however the method is aimed to be applied at large scale hydrodynamic models, and smaller effects are expected in downstream reaches.

All the intermediate outlet pixels over the segmented river (white squares in Figure 1c) are marked as checked. The algorithm then seeks for the next intermediate outlet with the largest drainage area (green square in Figure 1c) that is marked as not checked to proceed with the segmentation for the next tributary. Because the algorithm starts from an intermediate outlet (accumulated length $=0$ ) when tracing in the upstream direction, checked pixels must be neglected to avoid redefinition of some existing reaches. Following this rationale, the above procedure is repeated until the entire river network is completely segmented. Figure 2 a shows the result of the segmentation process, and reaches are distinguished by orange and green colors for visualization purposes. Finally, unit-catchments are defined in the same way as in the traditional
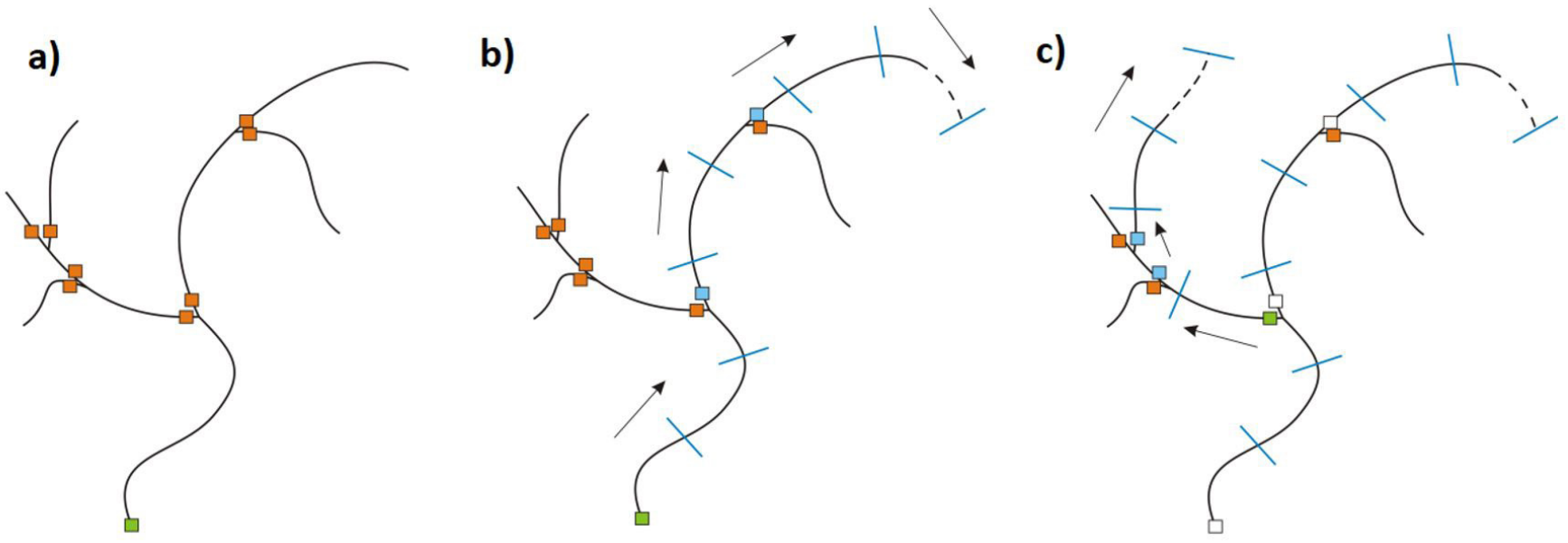

Figure 1. Delineating river reaches by a predefined length: (a) Marking intermediate (orange squares) and basin outlet (green square) points; (b) Segmentation from basin outlet (green square) and junction overpass following outlet pixels with highest accumulated area (blue squares); (c) Segmentation from the next intermediate outlet (green square), ranked in descending order of accumulated area. Outlet pixels along previously traced rivers (white squares) are ignored when selected for a new segmentation. Adapted from Siqueira et al. (2018, supplement). 

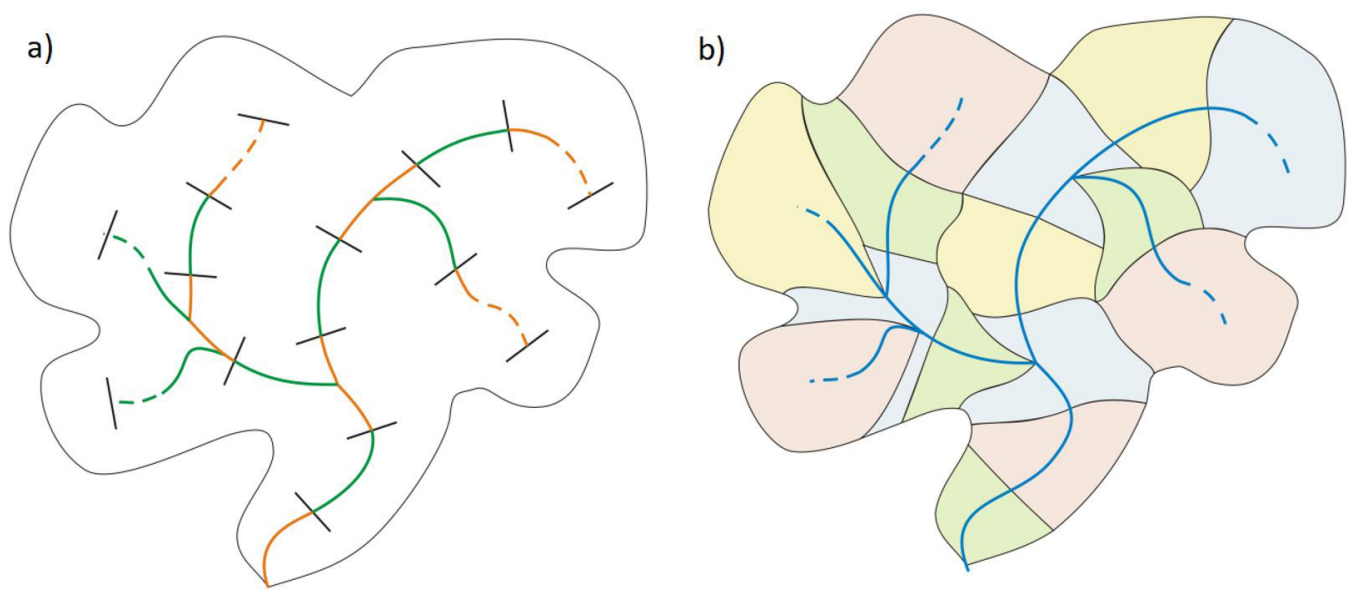

Figure 2. Fixed-length, vector-based discretization of the basin: (a) River reaches are separated by break lines and distinguished by colors orange and green; (b) Delineated unit-catchments based in all pixels draining to the same river reach. Adapted from Siqueira et al. (2018, supplement).

method, i.e., by identifying all pixels draining to the same river reach (or same ID). Therefore, model computational elements are constrained by topography and river lengths at the same time. Figure $2 \mathrm{~b}$ shows the spatial discretization of the basin as a result of the above method.

\section{The MGB model}

\section{Model description}

MGB is a conceptual, semi-distributed, hydrological model which has been widely used for large-scale modeling in South America from rapid-response basins to markedly seasonal and often slow response basins (Collischonn et al., 2007; Fan et al., 2015, 2017; Paiva et al., 2013; Siqueira et al., 2018; Fleischmann et al., 2019). In its most recent version, the basin is divided into unit-catchments (Paiva et al., 2011; Fan \& Collischonn, 2014; Pontes et al., 2017), each one containing a single river reach with an associated floodplain and hydrological vertical water and energy balance. Combinations of soil type and land use within each unit-catchment are categorized as Hydrological Response Units (HRU).

The soil water balance is computed independently for each HRU of each unit-catchment, where surface runoff is generated with excess of storage capacity considering a statistical distribution of water in soil. Canopy interception is represented as a function of Leaf Area Index (based on the approach by Wigmosta et al., 1994) and evapotranspiration is calculated using the Penman-Monteith equation. Groundwater and subsurface flows are computed, respectively, with linear and non-linear functions according to water availability in soil layer. Runoff generated from water balance at each HRU is routed to the stream network using linear reservoirs, considering effects such as attenuation and delay within the unitcatchment. Flow routing in the drainage network is computed using the Muskingum-Cunge method (Collischonn et al., 2007), 1D full hydrodynamic (Paiva et al., 2013) or more recently the inertial approximation of shallow water equations (Pontes et al., 2017).
Further details about the water balance module of MGB can be found in the general description presented by Collischonn et al. (2007) or by Siqueira et al. (2018).

Flow routing using local inertia equations

Regarding the river routing, flow in natural channels is usually represented by 1D full Saint Venant equations, expressed by continuity (Equation 1) and momentum conservation (Equation 2) equations:

$$
\frac{\partial A}{\partial t}+\frac{\partial Q}{\partial x}=0
$$

$$
\frac{\partial \boldsymbol{Q}}{\partial \boldsymbol{t}}+\frac{\partial\left(\boldsymbol{Q}^{2} / \boldsymbol{A}\right)}{\partial \boldsymbol{x}}+g \cdot A \cdot \frac{\partial h}{\partial x}=g \cdot A \cdot S_{0}-g \cdot A \cdot S_{f}
$$

where $Q$ is the river discharge $\left[\mathrm{m}^{3} \mathrm{~s}^{-1}\right], A$ is the flow cross-section area $\left[\mathrm{m}^{2}\right], b$ is the flow depth $[\mathrm{m}], z$ is the river bed elevation, relative to a datum $[\mathrm{m}] ; S_{o}$ is the channel bottom slope $\left[\mathrm{m} . \mathrm{m}^{-1}\right] ; S$ is the water surface slope $\left[\mathrm{m} . \mathrm{m}^{-1}\right]$; $\mathrm{g}$ is acceleration due to gravity $\left[\mathrm{m} \cdot \mathrm{s}^{-2}\right]$, and $n$ is the Manning's friction coefficient $\left[\mathrm{m}^{1 / 3} \mathrm{~s}\right]$.

MGB solves the momentum equation using the simple finite difference scheme proposed by Bates et al. (2010) and further tested by Almeida \& Bates (2013) and Fassoni-Andrade et al. (2018). In this method, the convective acceleration is neglected and flow variables in the friction term $(|\mathrm{Q}| \mathrm{Q})$ are written semi-implicitly $\left(\left|Q^{t}\right| Q^{t+\Delta t}\right)$, which in turn can be rearranged and solved with an explicit formulation as shown in Equation 3.

$$
Q_{i}^{t+\Delta t}=\frac{\left(\left(Q_{i}^{t}\right)-\text { g.B. } \Delta t \cdot\left(\text { hflow }_{i} \cdot \text { Sflow }_{i}\right)\right)}{\left(1+\frac{g \cdot \Delta t \cdot\left(\left|Q_{i}^{t}\right|\right) \cdot n^{2}}{B \cdot\left(\left(\text { hflow }_{i}\right)^{7 / 3}\right.}\right)}
$$

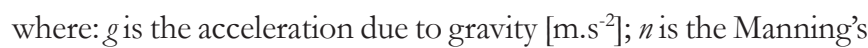
roughness coefficient; $\Delta t$ is the model time step $[\mathrm{s}] ; B$ is the channel width $[\mathrm{m}] ; \mathrm{Q}^{\mathrm{t}}$ and $\mathrm{Q}^{\mathrm{t}+\Delta \mathrm{t}}$ are, respectively, the flow from previous 
and current time step $\left[\mathrm{m}^{3} \cdot \mathrm{s}^{-1}\right]$; Sflow is the water surface slope $\left[\mathrm{m} \cdot \mathrm{m}^{-1}\right]$ and; hflow is the effective water depth between current and downstream unit-catchment $[\mathrm{m}]$.

The only prognostic variable is the total volume stored in channels and floodplains (Equation 4), whereas flow depth and discharge are derived from the total volume after solving the continuity and momentum equations, respectively. Evaporation losses are considered in Equation 4 by assuming flooded areas as open water and applying the Penman equation. Therefore, when flooding occurs in each unit-catchment, the surface area available for soil water balance is reduced proportionally from each HRU.

$\frac{V_{i}^{t+\Delta t}-V_{i}^{t}}{\Delta t}=\sum Q_{i n}^{t+\Delta t}-\sum Q_{o u t}^{t+\Delta t}-E v q_{i}+P_{i}$

where $V_{i}$ is the total volume stored in channel and floodplains, for unit-catchment $i\left[\mathrm{~m}^{3}\right] ; \mathrm{Q}_{\mathrm{in}}$ and $\mathrm{Q}_{\text {out }}$ are, respectively, the inflow and outflow discharge of unit-catchment $I\left[\mathrm{~m}^{3} \cdot \mathrm{s}^{-1}\right] ; E v q_{i}$ is the evaporation loss; $P_{i}$ the precipitation over open flooded areas $\left[\mathrm{m}^{3} \cdot \mathrm{s}^{-1}\right] ; t$ and $\Delta t$ denote the previous and current time step, respectively.

In order to respect the Courant-Friedrichs-Lewy (CFL) condition, the maximum acceptable time step is adaptive and changes according to maximum water depth, following Equation 5 (Bates et al., 2010):

$$
\ddot{A} t_{\max }=\alpha \frac{\Delta x}{\sqrt{g \cdot h \max }}
$$

where $\Delta x[\mathrm{~m}]$ is the river reach length; $\max [\mathrm{m}]$ is the maximum water depth in the model domain and; $\alpha$ is a coefficient lower than unity and $g$ is the acceleration due to gravity $\left[\mathrm{m} . \mathrm{s}^{-2}\right]$. In the case of MGB, $\Delta x$ corresponds to the reach length chosen for the basin discretization (Pontes et al., 2017; Fleischmann et al., 2019). Further details about the flow routing equations of MGB model can be found in Pontes et al. (2017) and Siqueira et al. (2018).

Finally, regarding the fixed-length discretization described in this study, all tributaries contributing along a given river reach have their outlets artificially moved to the reach upstream point (i.e., green unit-catchments contributing to the blue unit-catchments at the center of Figure $2 b$ ).

Parameterization of floodplain topography and river hydraulics

The geometry of channel cross-sections is usually not available for large-scale basins. Hence, a very common approach is to adopt classic hydraulic geometry relationships for specific sites according to drainage area or discharge (Leopold \& Maddock, 1953). In the present research we assumed a rectangular channel, where the river cross-section geometry (i.e., bankfull depth and channel width) is parameterized with power law equations (Decharme et al., 2008; Yamazaki et al., 2011; Miguez-Macho \& Fan, 2012; Neal et al., 2012; Paiva et al., 2013; Domeneghetti, 2016; Luo et al., 2017).

Riverbed elevation can be roughly estimated using channel depth and riverbank height (i.e., channel top bank), the latter derived from a spaceborne DEM (Paiva et al., 2011; Yamazaki et al., 2011; Pontes et al., 2017). Since river bank height is a key parameter controlling flood frequency and extent (Miguez-Macho \& Fan, 2012), noise often present in terrain data should be preferably smoothed to reduce both negative and excessive slopes in the bed profile, which can lead to excessive inundation and numerical instabilities in the model. Therefore, to define channel top bank elevations a smoothing procedure is carried out through a simple linear regression, which is fitted to DEM values within each unitcatchment considering only pixels located over drainage networks. The riverbank height is set as the smoothed elevation associated to the center pixel of the river reach while DEM values remain unchanged (Siqueira et al., 2018). Finally, riverbed elevations are estimated subtracting the channel depths from the bank heights defined above.

To represent floodplain inundation, a hypsometric curve relating flow depth, flooded area and water volume stored in both floodplain and channel for a given unit-catchment is derived from its underlying DEM. Concepts of the HAND model (Rennó et al., 2008) were adopted to compute water volume emulating the inundation process from lower towards nearby higher areas, which is the same approach adopted in CaMa-Flood by Yamazaki et al. (2013). Volumes are calculated through the numerical integration of flooded area with flow depth at each time step.

Since the HAND method allows the whole DEM to be normalized for the drainage network (Rennó et al., 2008), the hypsometric curve becomes insensitive to riverbank height estimation, for instance when applying the smoothing procedure. Nevertheless, it is worth mentioning that DEM conditioning procedures such as raising or lowering pixels (e.g., Yamazaki et al., 2012; Hoch et al., 2017) are not conducted here prior to riverbed and floodplain geometry estimation, so that elevations are maintained as close as possible to the original topographic data.

\section{Study area}

The Purus River is one of the main tributaries of the Amazon River (Figure 3) with a drainage area of $370,000 \mathrm{~km}^{2}$ and average discharge of $11,000 \mathrm{~m}^{3} \mathrm{~s}^{-1}$ (Paiva et al., 2011). Land cover is mainly forest. Extensive floodplains ("várzeas") exist along the river which lead to major hydrograph attenuation, with the floodplain to channel width ratio reaching values as high as 30 (Melack \& Hess, 2010; Junk et al., 2011; Paiva et al., 2011; Fleischmann et al., 2016). Surface water slopes are generally small $(<5 \mathrm{~cm} / \mathrm{km})$, and relevant backwater effects occur from the Amazon mainstem (Meade et al., 1991). We choose the Purus basin as the study case for the following reasons: (i) MGB was successfully applied in a previous work with hydrodynamic modeling (Paiva et al., 2011); and (ii) the existence of a strongly seasonal flood pulse and extensive floodplains in the lower portion of the basin.

\section{Input data}

\section{GIS processing}

We performed the GIS processing in two steps. Firstly, D8 flow directions and drainage networks were extracted from the SRTM DEM version 4 (Jarvis et al., 2008) using a GIS package 


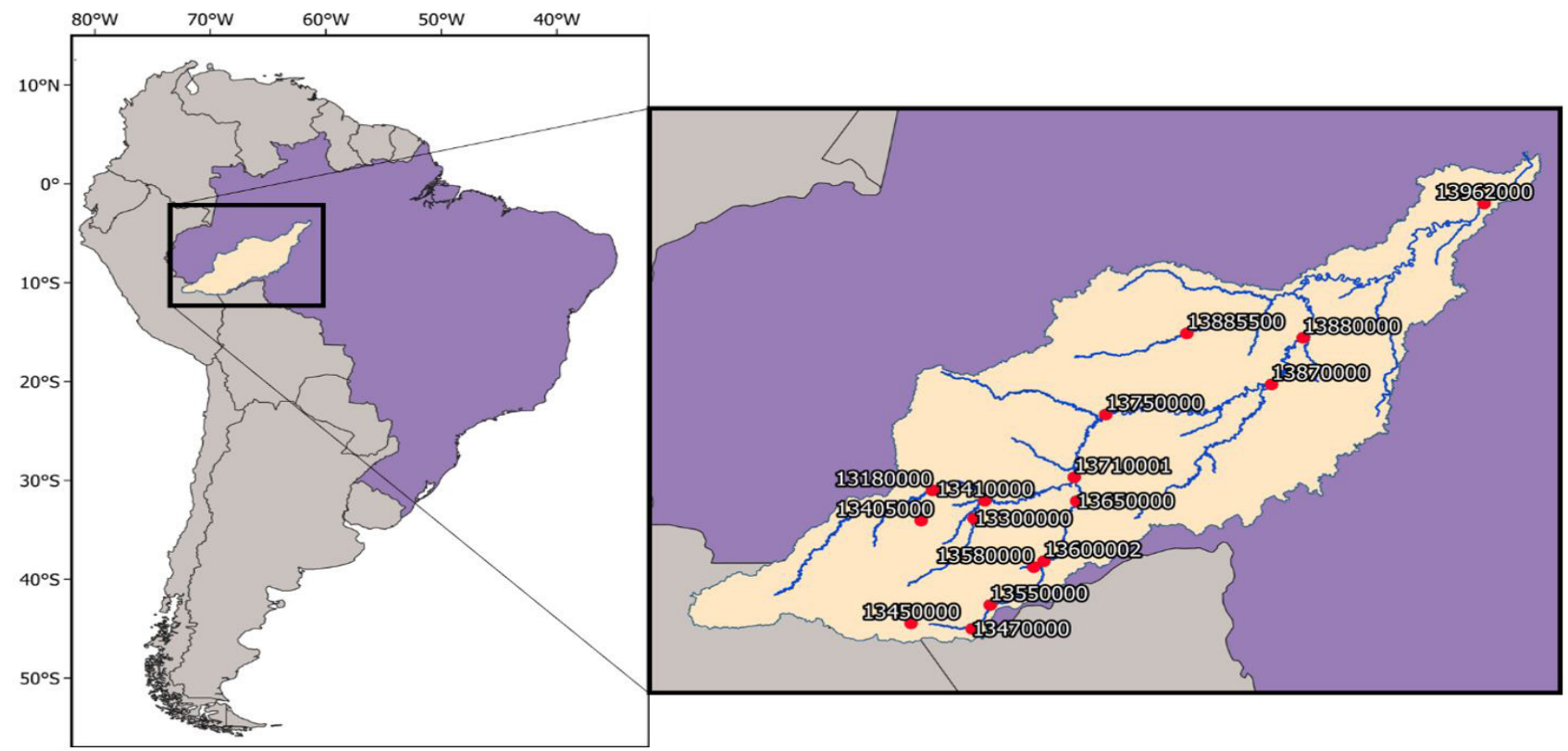

Figure 3. Purus basin location. Red dots are the available in-situ discharge gauges, with their respective identification code (see Table 1).

called IPH-Hydro Tools (Siqueira et al., 2016). Second, to estimate floodplain topography, we computed the HAND values using drainage networks and flow directions derived above together with the Bare-Earth SRTM DEM version 1, which combines multiple remote sensing datasets in order to reduce vegetation biases on SRTM Data (O'Loughlin et al., 2016).

Spatial resolution of both SRTM and Bare Earth SRTM datasets were resampled from 3 to 15 -arcsec in order to reduce computational burden during GIS data processing. We choose to not derive flow directions directly from the Bare-Earth SRTM because the delineation of drainage networks is hampered by the vegetation removal. This is reasonable because in the original DEM the riparian vegetation helps delineating the presence of the water courses, once the elevation values are higher around the river.

The vegetation-removed DEM leads to a flat area along the river floodplain that can hinder a proper river delineation, since the flatter is the terrain, more complicated is to obtain flow directions. However, for other steps in the hydrodynamic model parameterization, especially related to the estimation of floodplain topography, the use of vegetation-removed DEMs is fundamental.

We used a minimum area threshold of $625 \mathrm{~km}^{2}$ to match the resolution of the Multi-Source Weighted Ensemble Precipitation - MSWEP (Beck et al., 2017) precipitation grid cells $\left(0.25^{\circ} \times 0.25^{\circ}\right.$; see description below).

\section{Land use, soil and hydrological data}

The soil map used is a combination of the Brazilian database of soils and the Digitized Soil Map of the World and Derived Soil Properties (Food and Agriculture Organization, 2003), the latter needed to account for areas lying outside the Brazilian national limits. Land use classification was retrieved from the Global Land Cover map (Arino et al., 2012), a product generated using Envisat MERIS fine-resolution (300 m) satellite imagery over the year of 2009. Regarding the hydrological data, time series of river discharge and river stage were provided by the Brazilian National Water Agency (ANA - Agência Nacional de Águas) at daily time interval. The same hydrologic response units map was used by previous studies using the MGB model: Siqueira et al. (2018), Lopes et al. (2018), Pontes et al. (2017), Fan et al. (2014, 2016), Schwanenberg et al. (2015), among others.

\section{Meteorological forcing}

Two meteorological datasets were used as input to MGB water balance module. The Multi-Source Weighted Ensemble Precipitation - MSWEP (Beck et al., 2017) was used as precipitation input, which is a $0.25^{\circ}$ global dataset that optimally combines satellite, gauge and reanalysis data. Climate forcing was derived from the CRU Global Climate v.2 (New et al., 2002), a dataset that provides long term monthly averages (period of 1961-1990) for all land areas at 10' resolution for relative humidity, wind speed, sunlight hours and surface air temperature.

\section{Experimental setup}

To understand the effects of spatial discretization on model results we performed the following steps:

1. Model performance: The model was calibrated using in situ observed discharges to provide a representative, reference run for all assessments. In this case, a fixed length discretization of $\Delta \mathrm{x}=10 \mathrm{~km}$ was adopted for river reaches within unit-catchments, and $\alpha=0.3$ was assumed as the adjustment factor to the routing time step resulting from CFL condition;

2. Spatial discretization visual inspection and statistical analysis: Purus basin was spatially discretized in river reaches with 
$\Delta \mathrm{x}=5 \mathrm{~km}, 10 \mathrm{~km}$ (default), $30 \mathrm{~km}$ and $50 \mathrm{~km}$, each one analyzed through visual inspection and from a statistical perspective;

3. Spatial discretization effects on model results: The model was run using the four different spatial discretizations (hereafter named only as $5 \mathrm{~km}, 10 \mathrm{~km}, 30 \mathrm{~km}$ and $50 \mathrm{~km}$ ) and results were intercompared in terms of discharges and water levels. As the purpose of these simulations is to isolate the effect of discretization, model parameters for each run were kept the same as for the default simulation. It is not expected great sensitivity of model parameters to the adopted $\Delta \mathrm{x}$ because the unit-catchment approach respects the topographical limits (as noted by Tesfa et al., 2014);

4. Numerical and computational aspects: Following the previous analyses, all model runs were compared in terms of both numerical stability and computational efficiency, the former evaluated through a mass balance assessment. For each unit-catchment and simulation interval, mass error $\left(\mathrm{M}_{\text {erro }}\right)$ in river storage was calculated based on Equation 4: $\mathrm{dV} / \mathrm{dt}=\mathrm{Q}_{\mathrm{in}}-\mathrm{Q}_{\text {out }}+\mathrm{M}_{\text {error }}$, which can be rearranged in the accumulated form (total error) as (Equation 6):

$M_{\text {error }}=\sum_{t=1}^{N T} \sum_{i=1}^{N U}\left[\begin{array}{l}V_{i}^{t}-V_{i}^{t-1}-\left(\operatorname{Qin}_{i}^{t}-\text { Qout }_{i}^{t}\right) * 86400- \\ \left(\text { Pflood }_{i}^{t}-\text { Eflood }_{i}^{t}\right) * \text { Aflood }_{i}^{t} * 1000\end{array}\right]$

where: $i$ is the unit-catchment index; $\mathrm{NU}$ is the total number of unit-catchments; $t$ is the time step of simulation; NT is the total number of time steps [days]; $V_{i}^{t}$ e $V_{i}^{t-1}$ are the river storages (channel + floodplain) at current and previous time intervals, respectively $\left[\mathrm{m}^{3}\right] ; \operatorname{Qin}_{i}^{t}$ e Qout $_{i}^{t}$ are the inflows (from local runoff + upstream tributaries) and outflows at unit-catchment $i$, respectively $\left[\mathrm{m}^{3} \mathrm{~s}^{-1}\right]$; $\operatorname{Pflood}_{i}^{t}$ is the precipitation over the flooded area $[\mathrm{mm}] ;$ Eflood $_{i}^{t}$ is the open water evaporation in floodplain $[\mathrm{mm}] ;$ Aflood $_{i}^{t}$ the flooded area at unit-catchment $i\left[\mathrm{~km}^{2}\right] ; 86400$ is a time conversion factor (from seconds to days).

5. Flow limiter test: The MGB model was run using the four spatial discretizations but considering a flow limiter in which the maximum allowed discharge between neighbor unit-catchments is the one that leads to Froude Number $\left(F r=\frac{v}{\sqrt{g h}}\right)$ equal or less than one. The flow limiter does not imply mass imbalance (e.g., in flooded areas) because it limits only the flow between unit-catchments (i.e., reduce instantaneous discharges), so that the total water is always conserved in the system due to the continuity equation (Equation 1).

All simulations were performed using an Intel i5 2.2Ghz processor with $8 \mathrm{~GB}$ of RAM. The $10 \mathrm{~km}$ reach-length was chosen as the reference value because it is a value commonly used in MGB model previous studies (Pontes et al., 2017; Fleischmann et al., 2019).
Model performance was assessed by three comparison statistics: the Nash-Sutcliffe Efficiency - NSE (Nash \& Sutcliffe, 1970); the Kling-Gupta Efficiency - KGE (Kling et al., 2012); and the Delay Index - DI (Paiva et al., 2013). The latter consists in the time delay (in days) that leads to the highest Pearson correlation between observed and the simulated discharges. These performance metrics correspond to a 10 -year simulation period from $01 / 01 / 2000$ to $31 / 12 / 2009$ (reference run).

\section{RESULTS AND DISCUSSIONS}

\section{Model adjustment}

In general, model performance in Purus basin was considered satisfactory (Table 1). For gauges located in smaller drainage areas, KGE values were mainly between 0.6 and 0.9 , while NSE values were around 0.55 and 0.75 . For larger drainage areas $\left(>60,000 \mathrm{~km}^{2}\right), \mathrm{KGE}$ and NSE values were always greater than 0.85 . DI values were all between -1 and 5 days, being among -1 to 1 in 11 of the 14 locations studied.

\section{Spatial discretization visual inspection and statistical analysis}

Information regarding the spatial discretization is given by Figure 4 and Table 2. Figure $4 \mathrm{a}$ and Figure $4 \mathrm{~b}$ show a colored visual example of the differences between the discretizations. Despite the larger number of unit-catchments and river reaches in the $5 \mathrm{~km}$ (3064) in comparison to the $50 \mathrm{~km}$ (400) threshold, the catchment border between tributaries is maintained equal since the resulting irregular grid follows the underlying topography. Therefore, the spatial delineation of unit-catchments is more detailed only for main rivers with respect to downstream/upstream borders, and catchments considered as headwater remain unchanged independently on the adopted $\Delta \mathrm{x}$ (see the one located at the center of boxes in Figure 4a).

Table 1. MGB model performance to the Purus river basin test case.

\begin{tabular}{|c|c|c|c|c|c|}
\hline $\begin{array}{c}\text { Gauge } \\
\text { ID }\end{array}$ & Gauge Name & $\begin{array}{l}\text { Area } \\
\left(\mathrm{km}^{2}\right)\end{array}$ & KGE & NSE & $\begin{array}{c}\text { DI } \\
\text { (days) }\end{array}$ \\
\hline 13180000 & Manoel Urbano & 32800 & 0.72 & 0.58 & 0 \\
\hline 13300000 & Seringal Sao Jose & 11200 & 0.74 & 0.55 & -1 \\
\hline 13405000 & Seringal Guaraby & 6110 & 0.65 & 0.71 & 5 \\
\hline 13410000 & $\begin{array}{l}\text { Seringal da } \\
\text { Caridade }\end{array}$ & 63100 & 0.87 & 0.85 & 0 \\
\hline 13450000 & Assis Brasil & 3760 & 0.44 & 0.44 & 0 \\
\hline 13470000 & Brasileia & 7020 & 0.66 & 0.60 & -1 \\
\hline 13550000 & Xapuri & 8270 & 0.75 & 0.57 & -1 \\
\hline 13580000 & $\begin{array}{l}\text { Fazenda Santo } \\
\text { Afonso }\end{array}$ & 6330 & 0.84 & 0.73 & 1 \\
\hline 13600002 & Rio Branco & 23500 & 0.79 & 0.68 & -1 \\
\hline 13650000 & Floriano Peixoto & 34400 & 0.82 & 0.62 & 0 \\
\hline 13710001 & $\begin{array}{l}\text { Valparaiso } \\
\text { Montante }\end{array}$ & 105000 & 0.86 & 0.88 & 0 \\
\hline 13750000 & Seringal Fortaleza & 154000 & 0.93 & 0.94 & 0 \\
\hline 13870000 & Lábrea & 226000 & 0.93 & 0.94 & 3 \\
\hline 13880000 & Canutama & 236000 & 0.94 & 0.93 & 5 \\
\hline
\end{tabular}




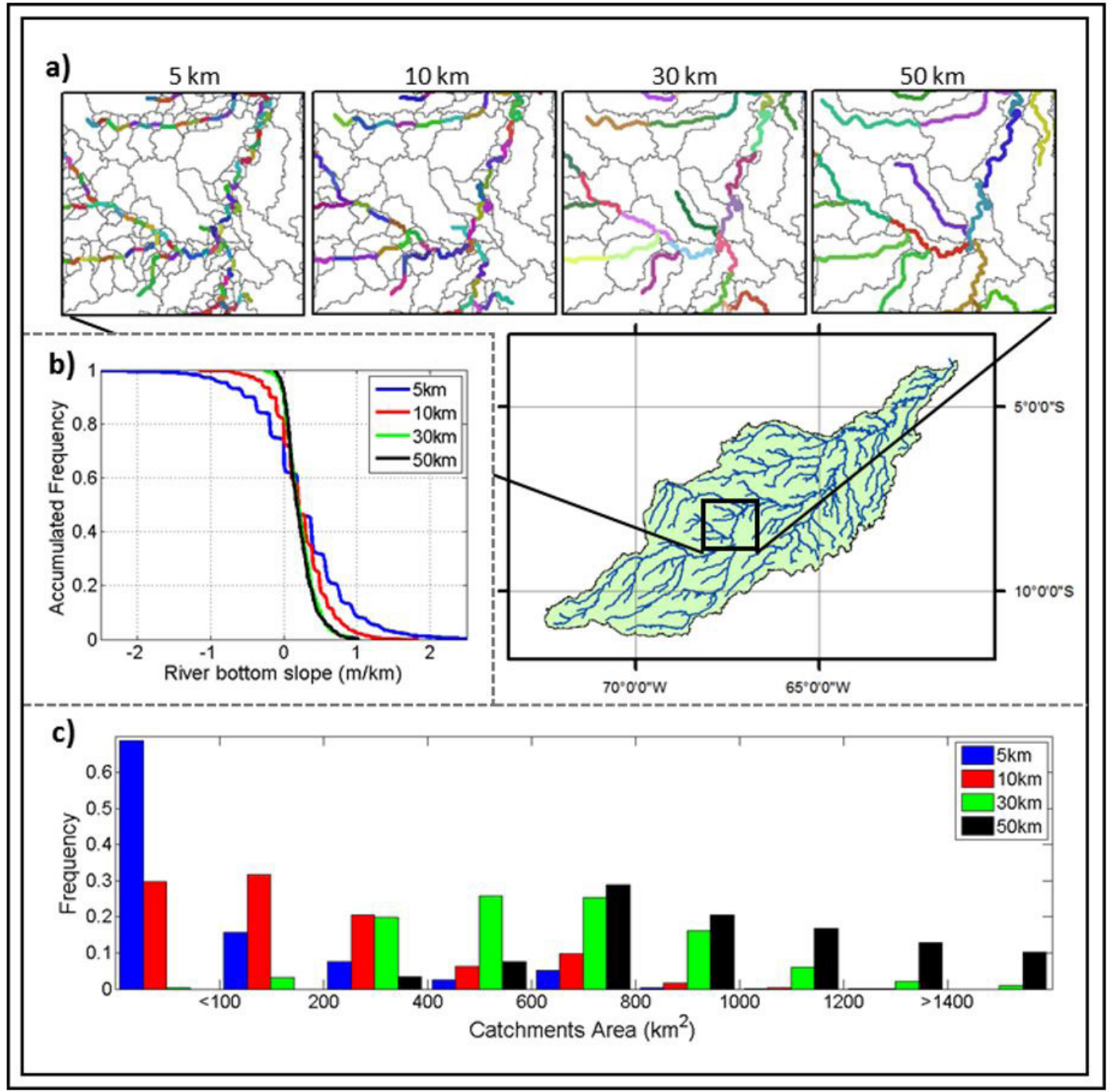

Figure 4. (a) Detail of fixed-length discretization (5, 10, 30 and $50 \mathrm{~km}$ ) within the corresponding box, with river reaches highlighted by different colors; (b) Accumulated frequencies of river bottom slope for each discretization; (c) Histogram of unit-catchment areas for each discretization. Colors in "a" do not refer to colors in "b" and "c".

Table 2. Unit-catchment areas and reach lengths for different spatial discretization in the Purus river basin.

\begin{tabular}{|c|c|c|c|c|c|c|c|c|c|}
\hline & \multicolumn{4}{|c|}{ Unit-catchments area $\left(\mathrm{km}^{2}\right)$} & \multicolumn{4}{|c|}{ Length of river reaches $(\mathrm{km})$} \\
\hline & & $5 \mathrm{~km}$ & $10 \mathrm{~km}$ & $30 \mathrm{~km}$ & $50 \mathrm{~km}$ & $5 \mathrm{~km}$ & $10 \mathrm{~km}$ & $30 \mathrm{~km}$ & $50 \mathrm{~km}$ \\
\hline \multicolumn{2}{|c|}{ Number of unit-catchments } & 3064 & 1613 & 607 & 400 & 3064 & 1613 & 607 & 400 \\
\hline \multicolumn{2}{|c|}{ Average } & 123.7 & 234.9 & 624.3 & 947.3 & 5.31 & 10.32 & 30.41 & 50.28 \\
\hline \multicolumn{2}{|c|}{ Standard deviation } & 167.8 & 215.1 & 277.6 & 340.3 & 0.23 & 0.25 & 0.31 & 1.17 \\
\hline \multicolumn{2}{|c|}{ Coefficient of variation } & 1.36 & 0.92 & 0.44 & 0.36 & 0.04 & 0.02 & 0.01 & 0.02 \\
\hline \multirow[t]{5}{*}{ Quantiles } & $5 \%$ & 14.0 & 41.4 & 234.7 & 467.9 & 4.93 & 9.93 & 30.00 & 49.88 \\
\hline & $25 \%$ & 32.1 & 89.7 & 410.0 & 702.9 & 5.16 & 10.13 & 30.18 & 50.19 \\
\hline & $50 \%$ & 59.5 & 149.3 & 606.4 & 896.3 & 5.32 & 10.29 & 30.36 & 50.41 \\
\hline & $75 \%$ & 125.0 & 283.4 & 803.6 & 1176.9 & 5.44 & 10.46 & 30.59 & 50.64 \\
\hline & $95 \%$ & 623.1 & 711.9 & 1105.6 & 1578.2 & 5.62 & 10.76 & 31.01 & 51.01 \\
\hline
\end{tabular}

Figure $4 \mathrm{c}$ shows the accumulated frequencies of river bottom slope $(\mathrm{m} / \mathrm{km})$ resulting from each model discretization. While the $5 \mathrm{~km}$ leads to bottom slopes varying from $-2.5 \mathrm{~m} / \mathrm{km}$ to $2.5 \mathrm{~m} / \mathrm{km}$, the $50 \mathrm{~km}$ smoothens the profiles, with bottom slopes varying from $-0.2 \mathrm{~m} / \mathrm{km}$ to $1.5 \mathrm{~m} / \mathrm{km}$. Negative slopes occur because no correction is carried out over the original DEM (i.e., Bare-Earth SRTM), which are more pronounced in river bottom profiles with short lengths since they are more affected by DEM noise in flat areas. As expected, unit-catchment areas are smaller for smaller reach lengths. For example, most of the unit-catchment areas for $5 \mathrm{~km}$ and $10 \mathrm{~km}$ are smaller than $200 \mathrm{~km}^{2}$. In turn, for the $30 \mathrm{~km}$ and $50 \mathrm{~km}$ discretization, areas were more concentrated between $200 \mathrm{~km}^{2}$ and $1200 \mathrm{~km}^{2}$, respectively. 
It can be noted that the fixed-length discretization does not lead to the exact $\Delta \mathrm{x}$ previously defined for unitcatchments. This occurs due to aspects related to the DEM resolution $(15 \operatorname{arcsec} \approx 450 \mathrm{~m}$ ), flow direction in adjacent pixels of river networks, especially in the border of unit-catchments (e.g., diagonal direction $=1.414 \mathrm{x}$ DEM resolution), and limitations in headwater river reaches with larger $\Delta \mathrm{x}$ (such as the $50 \mathrm{~km}$ ), since length is topographically limited by their upstream catchment boundaries.

Both local runoff and inflow of tributaries contributing along a given unit-catchment are added to the very upstream point of this latter unit-catchment. So, the longer the river reach is, the longer will be the total distance for flow propagation. At the same time, increasing reach length also leads to smoothing

Table 3. Accumulated river lengths down to the Purus basin outlet (in $\mathrm{km}$ ) according to $\Delta \mathrm{x}$. Length accumulation is computed individually for each unit-catchment and results are summarized in percentiles of 25,50 and $75 \%$.

\begin{tabular}{ccccc}
\hline Percentiles of & \multicolumn{4}{c}{ Discretization $\mathbf{\Delta x}$} \\
\cline { 2 - 5 } unit-catchments & $\mathbf{5} \mathbf{~ k m}$ & $\mathbf{1 0} \mathbf{~} \mathbf{m}$ & $\mathbf{3 0} \mathbf{~} \mathbf{m}$ & $\mathbf{5 0} \mathbf{~} \mathbf{m}$ \\
\hline $25 \%$ & 1152.5 & 1157.8 & 1181.4 & 1230.9 \\
$50 \%$ (median) & 1586.5 & 1591.3 & 1604.3 & 1657.1 \\
$\mathbf{7 5 \%}$ & 2226.5 & 2236.0 & 2239.7 & 2286.8 \\
\hline
\end{tabular}

of river channel slopes. This can reduce the flood wave celerity and cause flows to be attenuated (in conditions without the effect of floodplains). However, differences in total river length were relatively small. Table 3 shows how total river length (down to the basin outlet) can change according to the adopted reach length.

\section{Spatial discretization effects on model results}

In this section, impacts of the spatial discretization on model results are evaluated using the same simulation period of the reference run. Results for discharge, flow depth and water level anomalies, at three locations (gauges $1355000\left(3760 \mathrm{~km}^{2}\right)$, $13650000\left(34,400 \mathrm{~km}^{2}\right)$, and $13880000\left(236,000 \mathrm{~km}^{2}\right)$ ), are given by Figure 5 for the period between 2004 and 2006. To complement the analysis, Figure 6 shows a comparison between maximum and minimum (full period - calibration and validation) calculated discharges at each unit-catchment and for each discretization. For this, we computed the mean of minimum and maximum discharges of independent events that met a pre-defined flow threshold, i.e. (local) low flows below $\mathrm{Q}_{80}$ (lower values from the flow duration curve) and peak flows higher than $\mathrm{Q}_{20}$ (higher values from the flow duration curve) of the simulated time series. In general, discharge seems to be not largely affected by the adopted $\Delta x$. As an integrative variable that depends on all discharge generated in a)
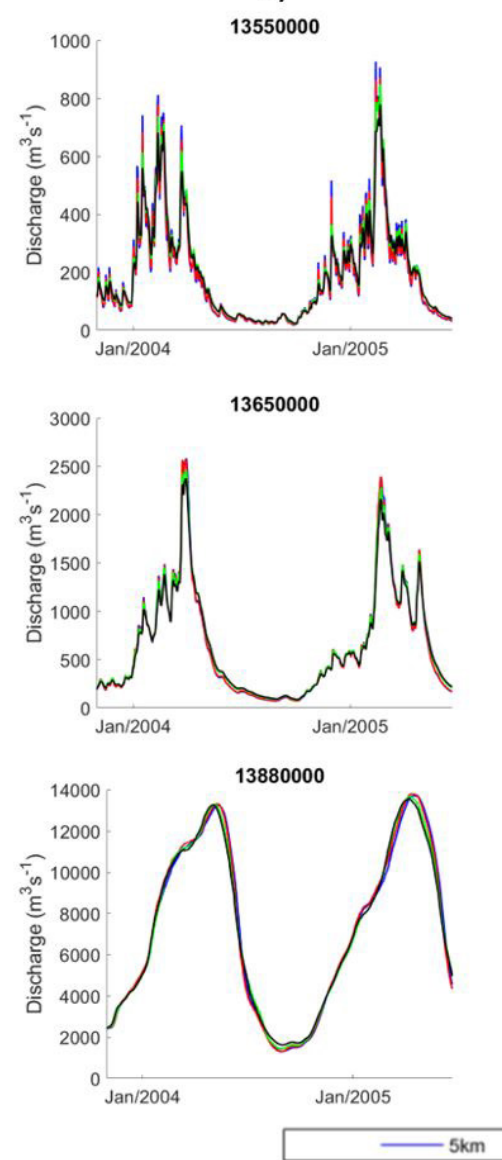

b)

13550000
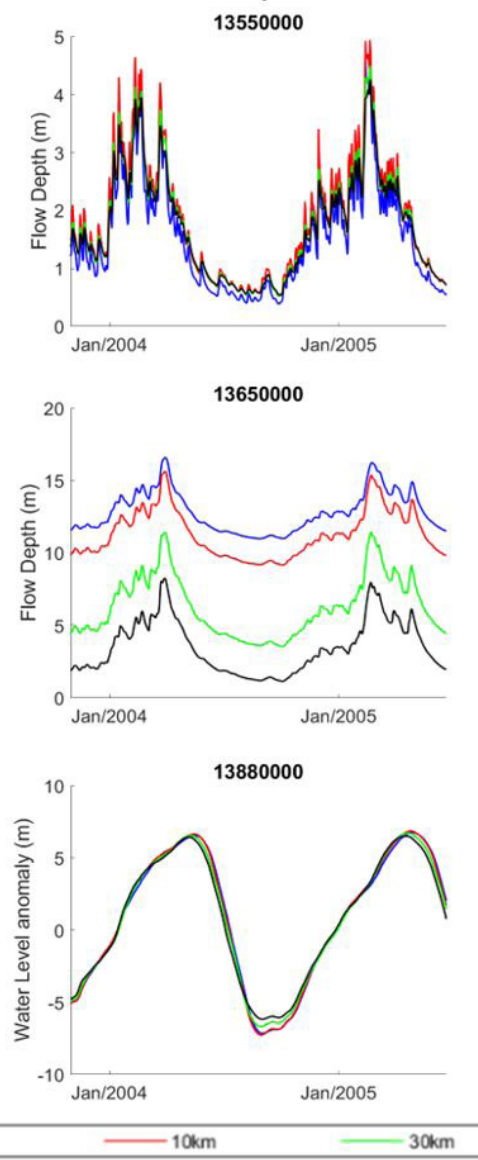

c)

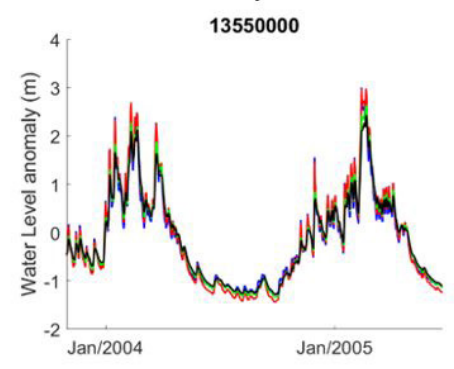

13650000
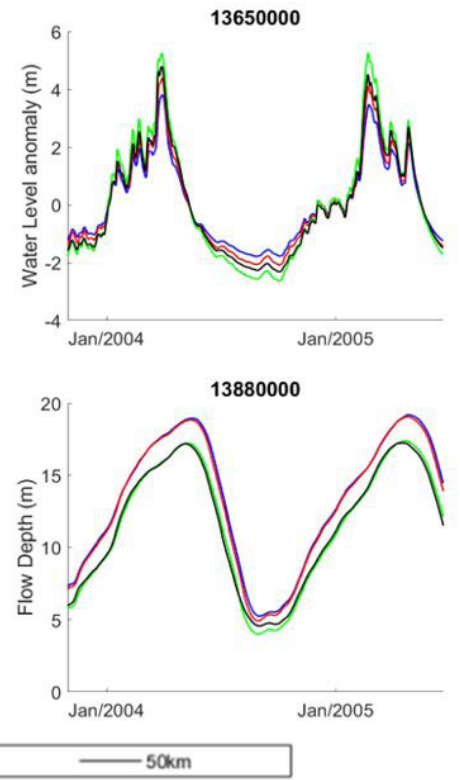

Figure 5. Model results for the $5 \mathrm{~km}, 10 \mathrm{~km}, 30 \mathrm{~km}$ and $50 \mathrm{~km}$ discretizations at gauges $1355000\left(3760 \mathrm{~km}^{2}\right), 13650000\left(34,400 \mathrm{~km}^{2}\right)$, and $13880000\left(236,000 \mathrm{~km}^{2}\right)$ for (a) discharge; (b) flow depth; and (c) water level anomalies. 
a)

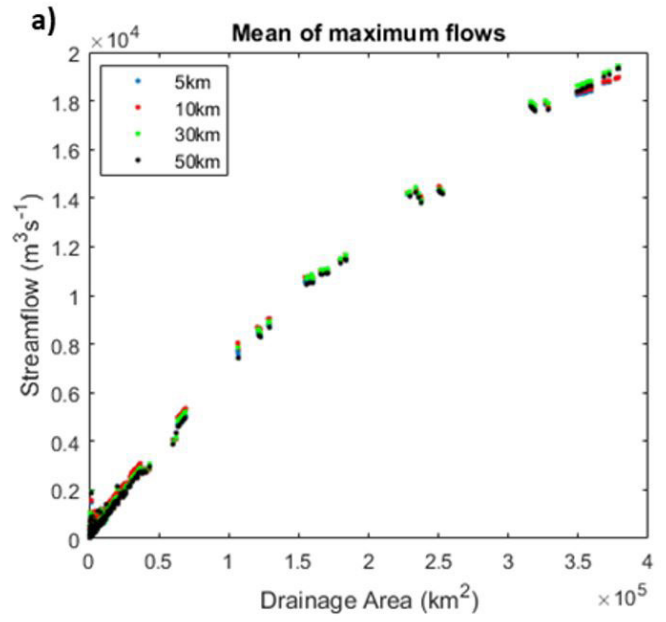

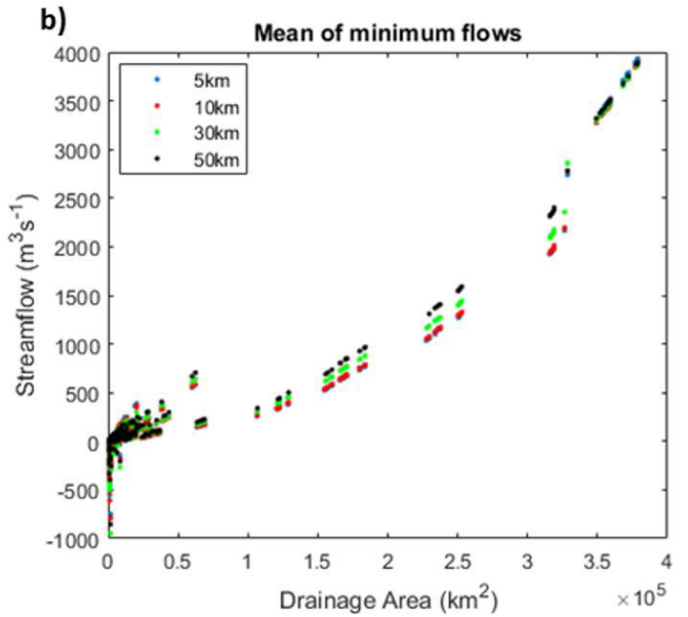

Figure 6. Comparison between calculated discharges at each unit-catchment for each spatial discretization: (a) mean of maximum; and (b) mean of minimum.

the upstream areas, discharges are less sensitive to smaller changes in the volumes of individual reaches. Hydrographs tended to be similar independently of the reach length (Figure 5a), while slightly higher differences appeared on the extreme values. The only exception was observed for minimum discharge values at intermediate drainage areas (Figure $5 \mathrm{~b}$ ). For an area of $2.5 \times 10^{5} \mathrm{~km}^{2}$ the minimum flow varied between $1500 \mathrm{~m}^{3} \mathrm{~s}^{-1}$ (50 km reaches) and $1300 \mathrm{~m}^{3} \mathrm{~s}^{-1}$ (5 $\mathrm{km}$ and $1 \mathrm{~km}$ reaches).

The differences in minimum flows at intermediate drainage areas can be related to the flow depth (Figure 5b). As one can see, the flow depth largely differs between the tested reach lengths at the gauge $13650000\left(34,400 \mathrm{~km}^{2}\right)$, which is a representative point of intermediate drainage areas. At gauge 13650000, the $50 \mathrm{~km}$ reach length simulated flow depth was $10 \mathrm{~m}$ lower than the $5 \mathrm{~km}$ reach length simulation. With a lower depth, the $50 \mathrm{~km}$ simulation has lesser flooding areas, resulting in more in-bank flow during higher discharges, as water does not flow to floodplains in these cases. For this reason, simulated flows with smaller $\Delta \mathrm{x}$ tend to be delayed in comparison to the ones obtained with larger reach lengths, as observed in gauge 13880000 .

At other scales these effects are not as important as found in the intermediate scale. In the smaller scale (gauge 1355000 $3760 \mathrm{~km}^{2}$ ), differences are not much pronounced, and in larger scales (gauge $13880000236,000 \mathrm{~km}^{2}$ ) there is a difference of $2 \mathrm{~m}$ in the flow depth between discretizations of $50 \mathrm{~km} / 30 \mathrm{~km}$ and $10 \mathrm{~km} / 5 \mathrm{~km}$, which is not as expressive as the ones in the intermediate scales and not as expressive on discharges. Likewise, it is interesting to mention that $5 \mathrm{~km}$ and $10 \mathrm{~km}$ simulation results were also closer to each other in the larger scale, as the $30 \mathrm{~km}$ and $50 \mathrm{~km}$ were also similar between them.

\section{Numerical and computational aspects}

Computational burden and model instabilities related to numerical errors are relevant drawbacks of large-scale hydrodynamic routing. Besides, these problems are somehow linked: despite the adoption of a larger $\Delta \mathrm{x}$ can increase model time step and speedup computations for explicit schemes governed by the CFL condition (e.g., local inertial formulation), flow routing is more subject to mass balance errors because numerical issues usually arise from larger time steps. In this section we assess the impact of discretization on model efficiency and mass conservation to identify a tradeoff between both characteristics. Moreover, as the time step of the local inertial scheme computed by CFL condition can be adjusted by the $\alpha$ coefficient (Equation 7), we perform additional simulations with increasing $\alpha$ values $(0.4,0.5,0.6$ and $0.7)$ to assess the relevance of this parameter.

In order to provide a suitable comparison regarding numerical stability, total mass error $\left(M_{\text {error }}\right.$ described in Equation 6) was first expressed in terms of a mean discharge dividing $\mathrm{M}_{\text {error }}\left[\mathrm{m}^{3}\right]$ by the number of simulation time steps, thus producing an estimate of the flow error $\mathrm{Q}_{\text {error }}\left[\mathrm{m}^{3} \mathrm{~s}^{-1}\right]$. Further, the ratio between $\mathrm{Q}_{\text {error }}$ and the mean discharge of Purus basin at its outlet point was computed for each $\Delta \mathrm{x}$ and $\alpha$ value, and results were plotted against their respective simulation times (Figure 7).

According to results, the difference in processing times between discretizations can be considered relevant. While both simulations using $50 \mathrm{~km}$ and $30 \mathrm{~km}$ discretizations were completed in less than one minute even for lower $\alpha$ values, the simulation time for the $10 \mathrm{~km}$ reach varied between $2.5(\alpha=0.7)$ and 6 minutes $(\alpha=0.3)$. Also, the simulation time using the $5 \mathrm{~km}$ reach was around five times slower than the $10 \mathrm{~km}$ one, reaching a maximum simulation time of almost half an hour $(\alpha=0.3)$. Other than expected, model runs using different $\alpha$ values for the same $\Delta \mathrm{x}$ did not follow a linear pattern with respect to computational cost. This can be clearly seen for $\Delta \mathrm{x}=5 \mathrm{~km}$, since there is a major time difference in simulations with $\alpha$ between 0.3 and 0.4 when compared to the time difference with $\alpha$ between 0.6 and 0.7 . Regarding mass balance, the adoption of the lowest $\alpha(0.3)$ led to errors less than $0.01 \%\left(10^{-4}\right)$ in all simulations. As $\alpha$ increases, errors also increase, reaching almost $5000 \%$ when using $\Delta \mathrm{x}=50 \mathrm{~km}$ and $\alpha=0.7$. On the other hand, although the $5 \mathrm{~km}$ simulations resulted in relatively small errors, the associated simulation times were always the largest ones.

To further assess the impacts of the selected $\alpha$ value on model instabilities, boxplots of the Froude number $(\mathrm{Fr})$ for each previous 


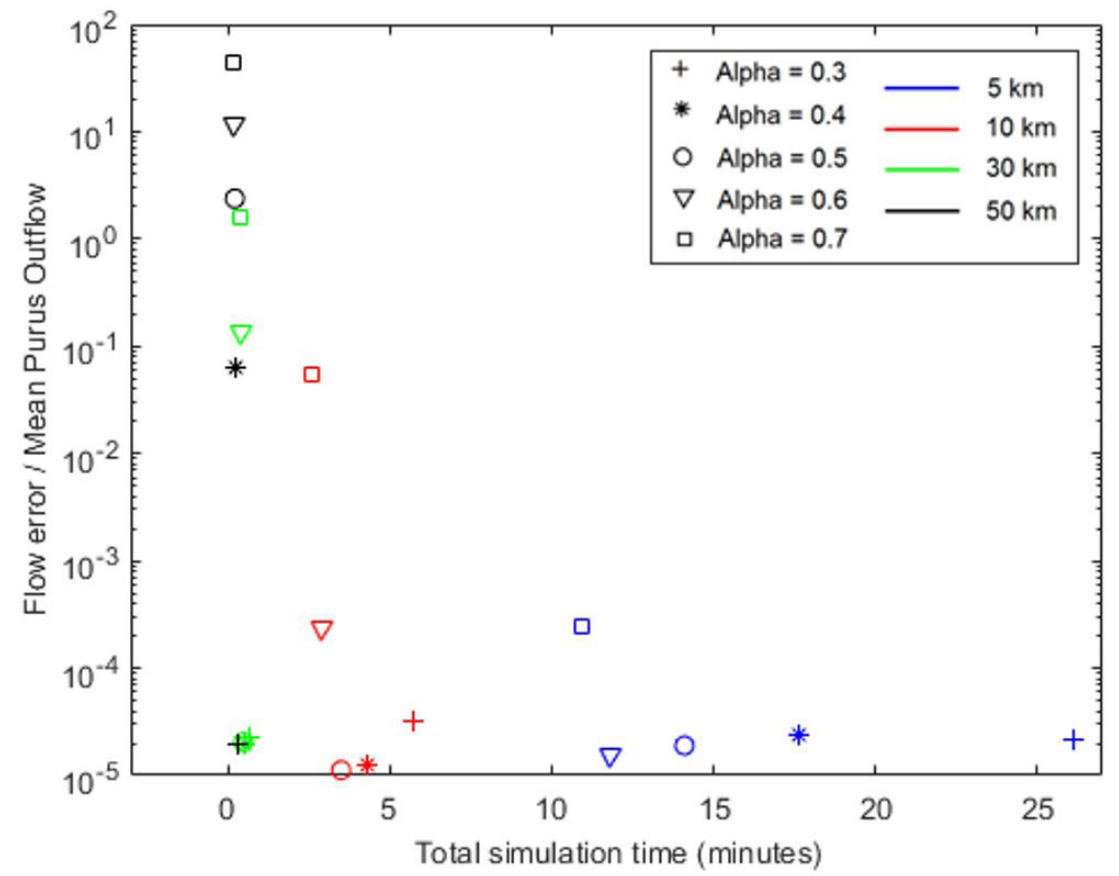

Figure 7. Mean Purus river simulated outflow error (in $\mathrm{m}^{3} / \mathrm{s}$ ) against the simulation time for each test performed.
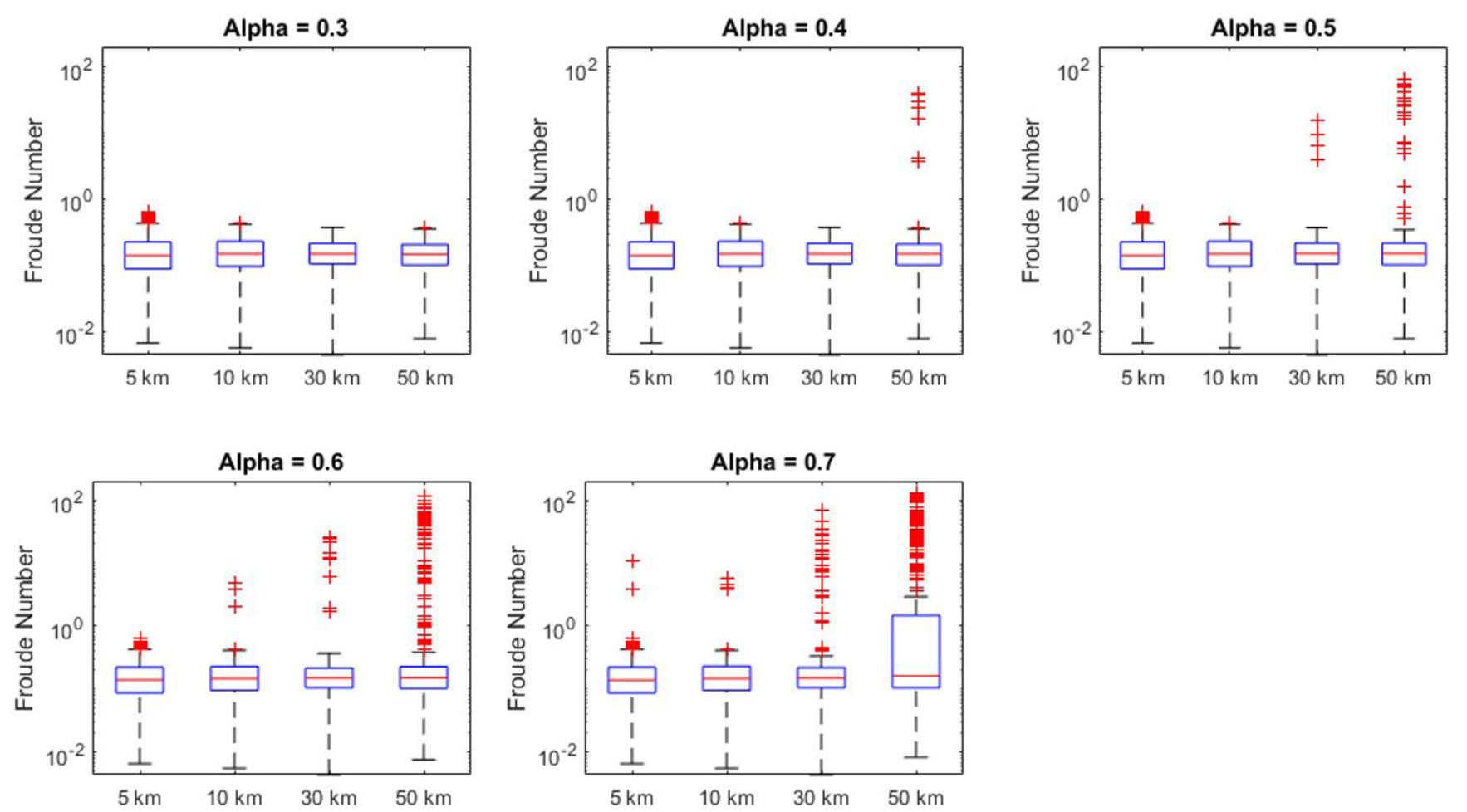

Figure 8. Boxplots comparing the tested discretizations against Froude numbers for all tested values of $\alpha$.

run were plotted in Figure 8. Each boxplot contains the maximum Fr value (considering the entire simulation period) of each unitcatchment for a given discretization, separated by different $\alpha$ values. As we can see, simulations with 5,10,30 and $50 \mathrm{~km}$ discretizations produce $\mathrm{Fr}$ values higher than unity (i.e., supercritical flows and associated numerical instabilities) for $\alpha$ values $\geq 0.7,0.6,0.5$ and 0.4 , respectively. To some extent, this agrees with results previously shown in Figure 7, albeit $\mathrm{Fr}>1$ not always led to significant mass errors (less than $0.1 \%\left[10^{-3}\right]$ for limit values of $\alpha$, except for the 50 $\mathrm{km}$ discretization). This indicates that numerical instabilities are likely to occur in some specific reaches, but errors are not necessarily propagated to other parts of the basin.

Figure 9 shows the evolution of model time step in the simulation period considering an $\alpha$ value of 0.7 . It is important 


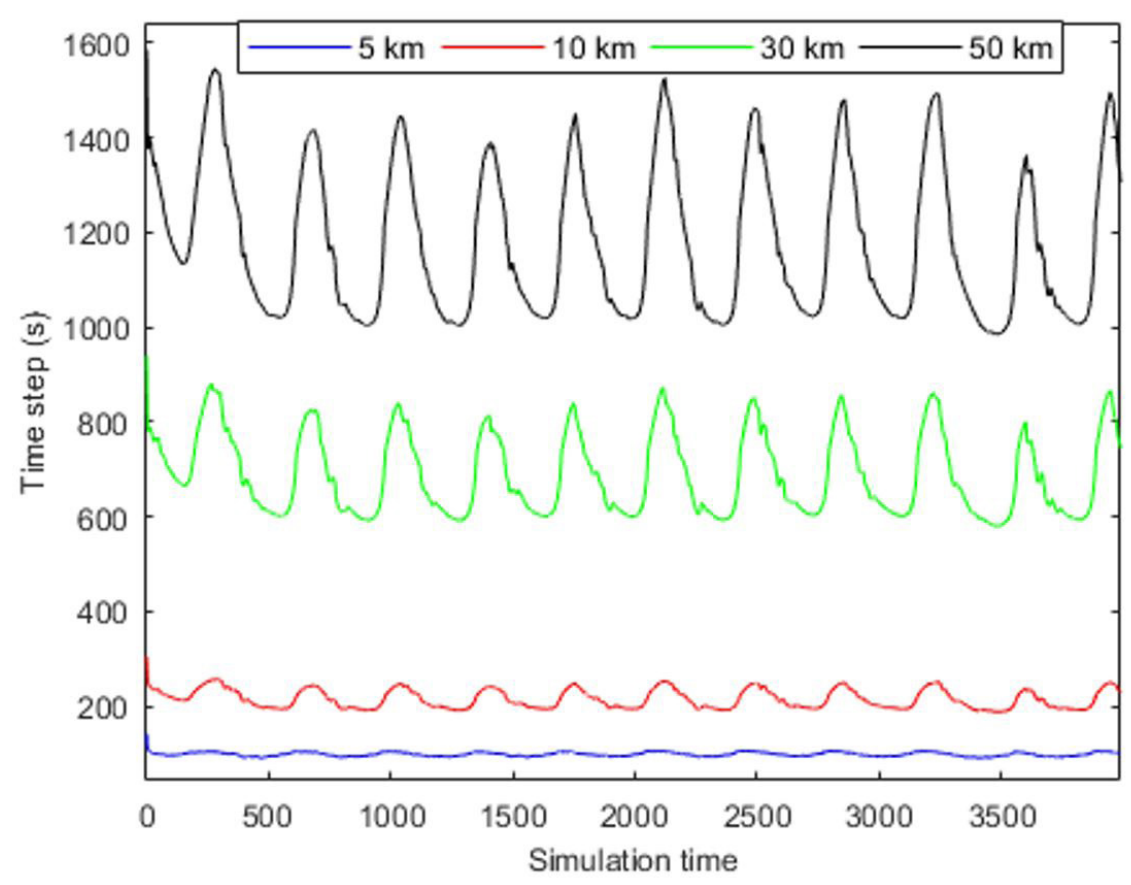

Figure 9. Time evolution of model time step for each discretization, considering an $\alpha=0.7$.

to highlight that the model time step is adaptive and calculated at each time interval by Equation 5, as flow depths are constantly changing over time. It can be noted that the $5 \mathrm{~km}$ simulation resulted in an almost constant $\Delta \mathrm{t}$ (around 100 seconds). These low and nearly constant values occur because a small $\Delta \mathrm{x}$ leads to more noisy river bottom profiles. Noisy bottom profiles can produce "artificial reservoirs" that increase flow depth at corresponding unit-catchments (see, for instance, gauge 13650000 in Figure 5), so that higher " $h$ " values are used to compute $\Delta \mathrm{t}$ through CFL condition (Equation 5), leading to lower $\Delta \mathrm{t}$ values. As the relative variation in flow depth tends to be low in cases with "artificial reservoirs", it consequently forces the model to keep a small time step for the entire simulation. In contrast, model time step in the $50 \mathrm{~km}$ simulation seems to be more adaptive to changes in flow depths (variations of $\Delta \mathrm{t}$ between 1000 and 1500 seconds), since bottom profiles are smoothed according to reach length, which results in lower water depths. That suggests that DEM correction methods with respect to noise reduction can be useful to reduce model time step in hydrodynamic simulations.

\section{Flow limiter test}

Previous tests indicated that the simulations can present numerical instabilities that lead to mass balance errors, even when using constant river reach lengths and adaptive time steps to control the CFL condition (Equation 7). These numerical issues were more relevant in simulations with longer river reaches (e.g., $50 \mathrm{~km}$ ), which are also the most computationally efficient ones. As longer reach lengths (e.g., $50 \mathrm{~km}$ ) would allow the best computational times, one interesting question is how to reduce their numerical instabilities in order to be able to adopt them in large scale models.
Then, in a final test we evaluated the usage of a simple flow limiter, based on the Froude number, by assessing the resulted oscillations and mass errors. The MGB model was run using the four tested spatial discretizations, using $\alpha$ values of 0.3 and 0.7 , and considering a flow limiter in which the maximum allowed discharge between unit-catchments is the one in which the instantaneous Froude Number is equal to one.

The adopted flow limiter led to almost zero mass errors, i.e. it was able to reduce mass error instabilities. However, although with no relevant mass error, some hydrograph oscillations persisted (visual inspection) in the simulated discharges with $\alpha=0.7$, while none was observed in the scenario with $\alpha=0.3$. Then, Figure 10 presents a spatial analysis of where these oscillations occurred in the scenarios with $\alpha=0.7$ when using the Froude flow limiter. Since the scenario with $\alpha=0.3$ did not present oscillations, we applied a simple method to evaluate in which reach occurred oscillations by computing the correlation (Pearson correlation) between discharges simulated with $\alpha$ equal to 0.3 and discharges simulated with $\alpha$ equal to 0.7 discharges. Oscillations in river reaches were classified into the following categories: no oscillations (correlation higher than 0.99), intermediate (correlation between 0.75 and 0.99 ) and large (correlation lower than 0.75 ) oscillations.

From our criteria, the usage of a flow limiter resulted in simulations with almost no discharge oscillations using $\alpha=0.7$ and reaches of $5 \mathrm{~km}$ and $10 \mathrm{~km}$. The $30 \mathrm{~km}$ simulation had some intermediate and large oscillations mainly at upstream reaches due to higher slopes, while the $50 \mathrm{~km}$ simulation led to a considerable number of oscillations over all the Purus basin, with a higher number of occurrences in the middle-upstream region.

From our perspective, a Froude number-based flow limiter helps to avoid mass balance errors and oscillations in general, but does not totally eliminate them, especially when a longer reach is used in the discretization. Our results show that a $\Delta \mathrm{x}$ of $30 \mathrm{~km}$ 


\section{Basin scale model oscillations with Froude flow limiter}

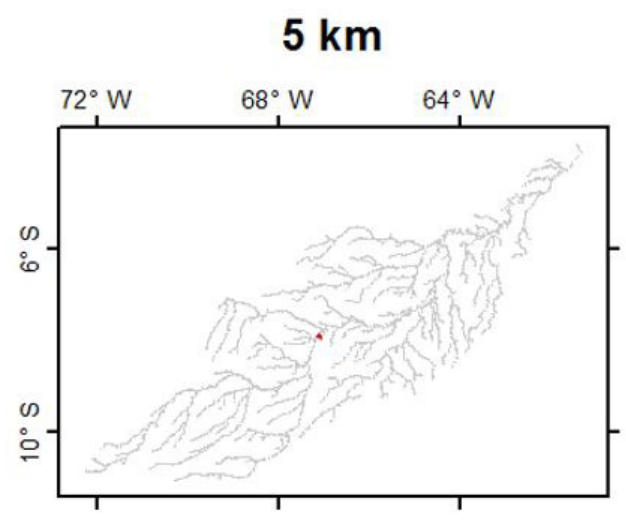

$30 \mathrm{~km}$

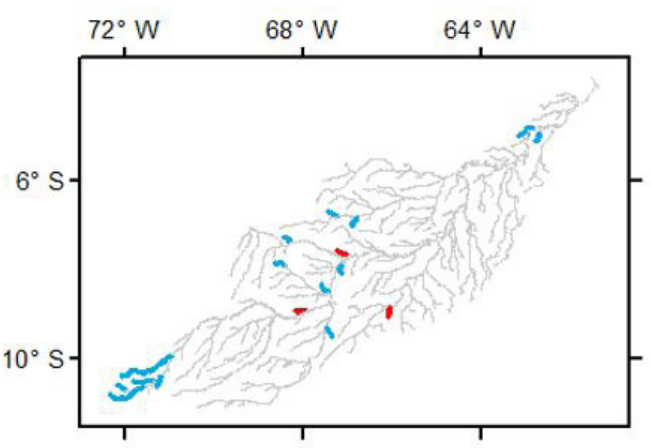

Legend

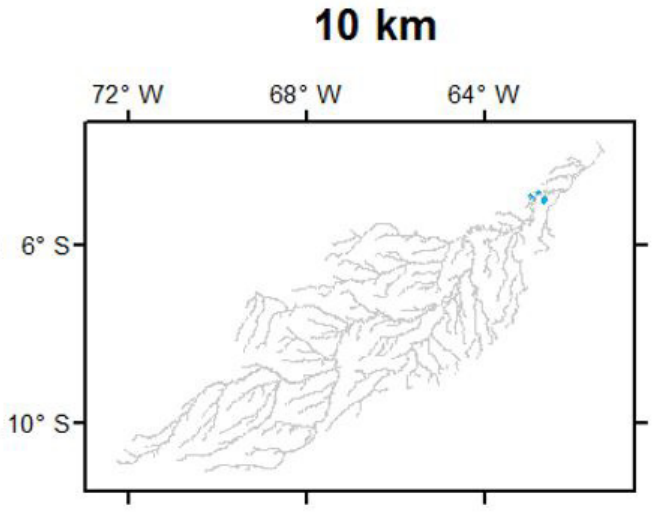

$50 \mathrm{~km}$

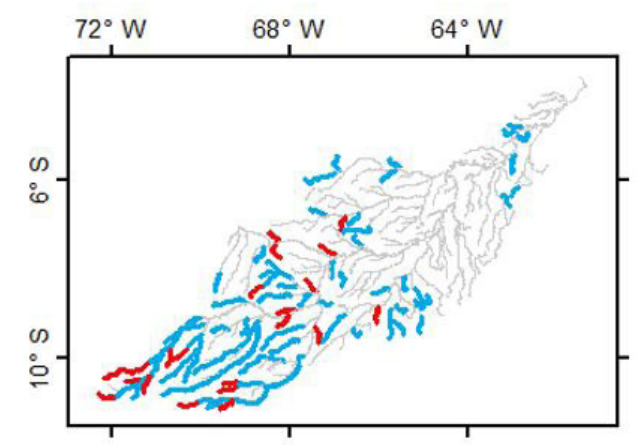

Large oscillations

\section{Intermediate}

No oscillations

Figure 10. Correlation between discharges simulated with $\alpha$ of 0.3 and 0.7 . Results are classified in Large $(r<0.75)$, intermediate $(0.75 \leq r<0.99)$ and no oscillations $(r \geq 0.99)$ in simulated hydrographs.

with the proposed Froude number-based flow limiter could be satisfactorily adopted to simulate the Purus river basin.

\section{CONCLUSIONS}

With the proposal of further understanding the effects of river network discretization on large-scale hydrologic-hydrodynamic models, the present research provided insights about relevant issues in setting up model configurations prior to a given application. Most of the insights were related to models which use the explicit local inertial approximation of shallow water equations (Bates et al., 2010) to perform flow routing, which is a usual setup for state-ofthe-art regional and continental models. Based on the obtained results, we consider that the main contributions of the study are:

- A fixed-length, vector-based discretization method can easily connect hydrological models that are built over topographical divisions (i.e., unit-catchments, sub-basins) to a hydrodynamic routing module;

- Anomalies of water level can be reasonably well simulated between different values of $\Delta x$, but this is not valid for flow depths. Therefore, a DEM correction method to reduce noise in river bottom profiles (or methods to ensure a correct profile representation) should be preferred if simulation of water surface elevations (or flood extent) is desired;

- For the explicit local inertial routing, $\Delta \mathrm{x}$ must be cautiously chosen together with a time step correcting factor $(\alpha)$ for CFL condition. Although more efficient in terms of processing time, a larger $\Delta \mathrm{x}$ is more subject to supercritical flows and numerical oscillations if small values of $\alpha$ are not adopted. Smaller $\Delta \mathrm{x}$ values demand more processing time, but present less numerical issues even for higher values of $\alpha$. For large-scale hydrological-hydrodynamic modeling encompassing entire basins, the use of low $\alpha$ values (such as 0.3 ) is recommended;

- A simple flow limiter based on Froude number can help to avoid numerical issues, but is not enough to eliminate flow oscillations, especially for the case of larger $\Delta \mathrm{x}$ and higher values of $\alpha$.

Finally, and summarizing all the contributions, we can state that a smaller $\alpha$ of the CFL condition had less impact in the total processing time for longer $\Delta \mathrm{x}$ and was satisfactorily applied to control the model stability. 


\section{REFERENCES}

Alfieri, L., Burek, P., Dutra, E., Krzeminski, B., Muraro, D., Thielen, J., \& Pappenberger, F. (2013). GloFAS-global ensemble streamflow forecasting and flood early warning. Hydrology and Earth System Sciences, 17(3), 1161-1175. http:/ /dx.doi.org/10.5194/ hess-17-1161-2013.

Almeida, G. A. M., \& Bates, P. (2013). Applicability of the local inertial approximation of the shallow water equations to flood modeling. Water Resources Research, 49(8), 4833-4844. http:/ /dx.doi. org/10.1002/wrcr.20366.

Archer, L., Neal, J. C., Bates, P. D., \& House, J. I. (2018). Comparing TanDEM-X data with frequently used DEMs for flood inundation modeling. Water Resources Research, 54(12), 10,205-10,222. http:/ / dx.doi.org/10.1029/2018WR023688.

Arino, O., Perez, R., Julio, J., Kalogirou, V., Bontemps, S., Defourny, P., \& Van Bogaert, E. (2012). Global Land Cover Map for 2009 (GlobCover 2009). Bremerhaven: European Space Agency (ESA) \& Université Catholique de Louvain (UCL), PANGAEA. http:/ / dx.doi.org/10.1594/PANGAEA.787668.

Bates, P. D., Horritt, M. S., \& Fewtrell, T. J. (2010). A simple inertial formulation of the shallow water equations for efficient two-dimensional flood inundation modelling. Journal of Hydrology, 387(1-2), 33-45. http://dx.doi.org/10.1016/j.jhydrol.2010.03.027.

Bates, P. D., Neal, J., Sampson, C., Smith, A., \& Trigg, M. (2018). Progress toward hyperresolution models of global flood hazard. In G. Michel (Ed.), Risk modeling for hazards and disasters (pp. 211232). Amsterdam: Elsevier. http://dx.doi.org/10.1016/B978-012-804071-3.00009-4.

Beck, H. E., Van Dijk, A. I. J. M., Levizzani, V., Schellekens, J., Miralles, D. G., Martens, B., \& Roo, A. D. (2017). MSWEP: 3-hourly $0.25^{\circ}$ global gridded precipitation (1979-2015) by merging gauge, satellite, and reanalysis data. Hydrology and Earth System Sciences, 21(1), 589-615. http://dx.doi.org/10.5194/hess-21-589-2017.

Beighley, R. E., Eggert, K. G., Dunne, T., He, Y., Gummadi, V., \& Verdin, K. L. (2009). Simulating hydrologic and hydraulic processes throughout the Amazon River Basin. Hydrological Processes, 23(8), 1221-1235. http://dx.doi.org/10.1002/hyp.7252.

Berry, P. A. M., Garlick, J. D., \& Smith, R. G. (2007). Near-global validation of the SRTM DEM using satellite radar altimetry. Remote Sensing of Environment, 106(1), 17-27. http://dx.doi.org/10.1016/j. rse.2006.07.011.

Biancamaria, S., Bates, P. D., Boone, A., \& Mognard, N. M. (2009). Large-scale coupled hydrologic and hydraulic modelling of the $\mathrm{Ob}$ River in Siberia. Journal of Hydrology, 379(1-2), 136-150. http:// dx.doi.org/10.1016/j.jhydrol.2009.09.054.

Bierkens, M. F. P. (2015). Globalhydrology 2015: State, trends, anddirections. Water Resources Research, 51(7), 4923-4947. http:// dx.doi.org/10.1002/2015WR017173.
Bravo, J. M., Collischonn, W., Paz, A. R., Allasia, D., \& Domecq, F. (2014). Impact of projected climate change on hydrologic regime of the Upper Paraguay River basin. Climatic Change, 127(1), 27-41. http://dx.doi.org/10.1007/s10584-013-0816-2.

Brêda, J. P. L. F., Bravo, J. M., \& Paiva, R. C. D. D. (2017). Efficient number of calibrated cross sections bottom levels on a hydrodynamic model using the SCE-UA algorithm. Case study: madeira River. Revista Brasileira de Recursos Hídricos, 22, 1. http:/ / dx.doi.org/10.1590/2318-0331.0217170068.

Buarque, D. C., Fan, F. M., Paz, A. R., \& Collischonn, W. (2009). Comparação de métodos para definir direções de escoamento a partir de modelos digitais de elevação. Revista Brasileira de Recursos Hídricos, 14, 91-103.

Butt, M. A., \& Maragos, P. (1998). Optimum design of Chamfer distance transforms. IEEE Transactions on Image Processing, 7(10), 1477-1484. PMid:18276213. http://dx.doi.org/10.1109/83.718487.

Carabajal, C. C., \& Harding, D. J. (2005). ICESat validation of SRTM C-band digital elevation models. Geophysical Research Letters, 32(22). http://dx.doi.org/10.1029/2005GL023957.

Chaudhari, S., Pokhrel, Y., Moran, E. F., \& Miguez-Macho, G. (2019). Multi-decadal hydrologic change and variability in the Amazon River Basin: understanding terrestrial water storage variations and drought characteristics. Hydrology and Earth System Sciences, 23(7), 2841-2862. http://dx.doi.org/10.5194/hess-23-2841-2019.

Collischonn, W., Allasia, D., Silva, B. C., \& Tucci, C. E. M. (2007). The MGB-IPH model for large-scale rainfall-runoff modelling, Hydrolog. Sci. J.-. Journal Des Sciences Hydrologiques, 52(5), 878-895. http://dx.doi.org/10.1623/hysj.52.5.878.

David, C. H., Maidment, D. R., Niu, G. Y., Yang, Z. L., Habets, F., \& Eijkhout, V. (2011). River network routing on the NHDPlus dataset. Journal of Hydrometeorology, 12(5), 913-934. http:/ /dx.doi. org/10.1175/2011JHM1345.1.

David, C. H., Yang, Z.-L., \& Hong, S. (2013). Regional-scale river flow modeling using off-the-shelf runoff products, thousands of mapped rivers and hundreds of stream flow gauges. Environmental Modelling \& Software, 42, 116-132. http://dx.doi.org/10.1016/j. envsoft.2012.12.011.

Decharme, B., Douville, H., Prigent, C., Papa, F., \& Aires, F. (2008). A new river flooding scheme for global climate applications: offline evaluation over South America. Journal of Geophysical Research, 113(D11), D11110. http://dx.doi.org/10.1029/2007JD009376.

Domeneghetti, A. (2016). On the use of SRTM and altimetry data for flood modeling in data-sparse regions. Water Resources Research, 52(4), 2901-2918. http://dx.doi.org/10.1002/2015WR017967.

Dung, N. V., Merz, B., Bárdossy, A., Thang, T. D., \& Apel, H. (2011). Multi-objective automatic calibration of hydrodynamic models utilizing inundation maps and gauge data. Hydrology and 
Earth System Sciences, 15(4), 1339-1354. http://dx.doi.org/10.5194/ hess-15-1339-2011.

Fan, F. M., \& Collischonn, W. (2014). Integração do modelo MGBIPH com Sistema de Informação Geográfica. Revista Brasileira de Recursos Hídricos, 19(1), 243-254. http://dx.doi.org/10.21168/ rbrh.v19n1.p243-254.

Fan, F. M., Collischonn, W., Meller, A., \& Botelho, L. C. M. (2014). Ensemble streamflow forecasting experiments in a tropical basin: the São Francisco river case study. Journal of Hydrology, 519, 29062919. http://dx.doi.org/10.1016/j.jhydrol.2014.04.038.

Fan, F. M., Pontes, P. R. M., Buarque, D. C., \& Collischonn, W. (2017). Evaluation of upper Uruguay river basin (Brazil) operational flood forecasts. Revista Brasileira de Recursos Hídricos, 22, 1-12. http:/ / dx.doi.org/10.1590/2318-0331.0217160027.

Fan, F. M., Schwanenberg, D., Alvarado, R., Reis, A. A., Collischonn, W., \& Naumann, S. (2016). Performance of deterministic and probabilistic hydrological forecasts for the short-term optimization of a tropical hydropower reservoir. Water Resources Management, 30(10), 3609-3625. http://dx.doi.org/10.1007/s11269-016-1377-8.

Fan, F. M., Schwanenberg, D., Collischonn, W., \& Weerts, A. (2015). Verification of inflow into hydropower reservoirs using ensemble forecasts of the TIGGE database for large scale basins in Brazil. Journal of Hydrology: Regional Studies, 4, 196-227.

Fan, F., Collischonn, W., Sorribas, M., \& Pontes, P. (2013). Sobre o início da rede de drenagem definida a partir dos modelos digitais de elevação. Revista Brasileira de Recursos Hídricos, 18(3), 241-257. http://dx.doi.org/10.21168/rbrh.v18n3.p241-257.

Farr, T. G., Rosen, P. A., Caro, E., Crippen, R., Duren, R., Hensley, S., Kobrick, M., Paller, M., Rodriguez, E., Roth, L., Seal, D., Shaffer, S., Shimada, J., Umland, J., Werner, M., Oskin, M., Burbank, D., \& Alsdorf, D. (2007). The shuttle radar topography mission. Reviews of Geophysics, 45(2), RG2004. http://dx.doi. org/10.1029/2005RG000183.

Fassoni-Andrade, A. C., Fan, F. M., Collischonn, W., Fassoni, A. C., \& Paiva, R. C. D. (2018). Comparison of numerical schemes of river flood routing with an inertial approximation of the Saint Venant equations. Revista Brasileira de Recursos Hidricos, 23, 1-16. http://dx.doi.org/10.1590/2318-0331.0318170069.

Fleischmann, A. S., Paiva, R. C. D., Collischonn, W., Sorribas, M. V., \& Pontes, P. R. M. (2016). On river-floodplain interaction and hydrograph skewness. Water Resources Research, 52(10), 7615-7630. http://dx.doi.org/10.1002/2016WR019233.

Fleischmann, A., Fan, F., Collischonn, B., Collischonn, W., Pontes, P., \& Ruhoff, A. (2019). Precipitation as a proxy for climate variables: application for hydrological modelling. Hydrological Sciences Journal, 64(3), 361-379. http://dx.doi.org/10.1080/0262 6667.2019.1587169.
Food and Agriculture Organization - FAO. (2003). The digitized soil map of the world and derived soil properties (version 3.5) (FAO Land and Water Digital Media Series, No. 1). Rome: FAO.

Goteti, G., Famiglietti, J. S., \& Asante, K. (2008). A CatchmentBased Hydrologic and Routing Modeling System with explicit river channels. Journal of Geophysical Research, 113(D14), D14116. http://dx.doi.org/10.1029/2007JD009691.

Hoch, J. M., Haag, A. V., van Dam, A., Winsemius, H. C., van Beek, L. P. H., \& Bierkens, M. F. P. (2017). Assessing the impact of hydrodynamics on large-scale flood wave propagation: a case study for the Amazon Basin. Hydrology and Earth System Sciences, 21(1), 117-132. http://dx.doi.org/10.5194/hess-21-117-2017.

Ikeuchi, H., Hirabayashi, Y., Yamazaki, D., Kiguchi, M., Koirala, S., Nagano, T., Kotera, A., \& Kanae, S. (2015). Modeling complex flow dynamics of fluvial floods exacerbated by sea level rise in the Ganges-Brahmaputra-Meghna Delta. Environmental Research Letters, 10(12), 124011. http://dx.doi.org/10.1088/1748-9326/10/12/124011.

Jarvis, A., Reuter, H. I., Nelson, A., \& Guevara, E. (2008). Hole-filled SRTM for the globe Version 4. Washington: CGIAR-CSI. Retrieved in 2020, April 17, from www.srtm.csi.cgiar.org

Jenson, S. K., \& Domingue, J. O. (1988). Extracting topographic structure from digital elevation data for geographic information system analysis. Photogrammetric Engineering and Remote Sensing, 54(11), 1593-1600.

Jones, R. (2002). Algorithms for using a DEM for mapping catchment areas of stream sediment samples. Computers \& Geosciences, 28(9), 1051-1060. http://dx.doi.org/10.1016/S0098-3004(02)00022-5.

Junk, W. J., Piedade, M. T. F., Schöngart, J., Cohn-Haft, M., Adeney, J. M., \& Wittmann, F. (2011). A classification of major naturallyoccurring amazonian lowland wetlands. Wetlands, 31(4), 623-640. http://dx.doi.org/10.1007/s13157-011-0190-7.

Kauffeldt, A., Wetterhall, F., Pappenberger, F., Salamon, P., \& Thielen, J. (2016). Technical review of large-scale hydrological models for implementation in operational flood forecasting schemes on continental level. Environmental Modelling \& Software, 75, 68-76. http://dx.doi.org/10.1016/j.envsoft.2015.09.009.

Kling, H., Fuchs, M., \& Paulin, M. (2012). Runoff conditions in the upper Danube basin under an ensemble of climate change scenarios. Journal of Hydrology, 424-425, 264-277. http://dx.doi. org/10.1016/j.jhydrol.2012.01.011.

Lehner, B., \& Grill, G. (2013). Global river hydrography and network routing: baseline data and new approaches to study the world's large river systems. Hydrological Processes, 27(15), 2171-2186. http://dx.doi.org/10.1002/hyp.9740.

Lehner, B., Verdin, K., \& Jarvis, A. (2006). HydroSHEDS technical documentation. Washington: World Wildlife Fund US. Retrieved in 2020, April 17, from http://hydrosheds.cr.usgs.gov 
Lehner, B., Verdin, K., \& Jarvis, A. (2008). New global hydrography derived from spaceborne elevation data. Eos, 89(10), 93-94. http:// dx.doi.org/10.1029/2008EO100001.

Leopold, L. B., \& Maddock, T. J. (1953). The bydraulic geometry of stream channels and some physiographic implications (Professional Paper, No. 252, 56 p.). Washington: U.S. Government Printing Office. http://dx.doi.org/10.3133/pp252.

Lin, P., Yang, Z., Gochis, D. J., Yu, W., Maidment, D. R., SomosValenzuela, M. A., \& David, C. H. (2018). Implementation of a vector-based river network routing scheme in the community WRF-Hydro modeling framework for flood discharge simulation. Environmental Modelling \& Software, 107, 1-11. http://dx.doi. org/10.1016/j.envsoft.2018.05.018.

Lopes, V. A. R., Fan, F. M., Pontes, P. R. M., Siqueira, V. A., Collischonn, W., \& Marques, D. M. (2018). A first integrated modelling of a river-lagoon large-scale hydrological system for forecasting purposes. Journal of Hydrology, 565, 177-196. http:// dx.doi.org/10.1016/j.jhydrol.2018.08.011.

Luo, X., Li, H.-Y., Leung, L. R., Tesfa, T. K., Getirana, A., Papa, F., \& Hess, L. L. (2017). Modeling surface water dynamics in the Amazon Basin using MOSART-Inundation v1. 0: impacts of geomorphological parameters and river flow representation. Geoscientific Model Development, 10(3), 1233-1259. PMid:32818050. http://dx.doi.org/10.5194/gmd-10-1233-2017.

Martz, L. W., \& Garbrecht, J. (1999). An outlet breaching algorithm for the treatment of closed depressions in a raster DEM. Computers \& Geosciences, 25(7), 835-844. http://dx.doi.org/10.1016/S00983004(99)00018-7.

Mateo, C. M. R., Yamazaki, D., Kim, H., Champathong, A., Vaze, J., \& Oki, T. (2017). Impacts of spatial resolution and representation of flow connectivity on large-scale simulation of floods. Hydrology and Earth System Sciences Discussions, 21(10), 5143-5163. http:// dx.doi.org/10.5194/hess-21-5143-2017.

Meade, R. H., Rayol, J. M., Da Conceição, S. C., \& Natividade, J. R. G. (1991). Backwater effects in the Amazon river of basin. Environmental Geology and Water Sciences, 18(2), 105-114. http:// dx.doi.org/10.1007/BF01704664.

Melack, J. M., \& Hess, L. L. (2010). Remote sensing of the distribution and extent of wetlands in the Amazon basin. In W. J. Junk, M. T. F. Piedade, F. Wittmann, J. Schöngart \& P. Parolin (Eds.), Amazonian floodplain forests: ecophysiology, biodiversity and sustainable management (pp. 43-59). Dordrecht: Springer. http:// dx.doi.org/10.1007/978-90-481-8725-6_3.

Miguez-Macho, G., \& Fan, Y. (2012). The role of groundwater in the Amazon water cycle: 1. Influence on seasonal streamflow, flooding and wetlands. Journal of Geophysical Research, 117(D15), D15113. http://dx.doi.org/10.1029/2012JD017539.
Mizukami, N., Clark, M. P., Sampson, K., Nijssen, B., Mao, Y., McMillan, H., Viger, R. J., Markstrom, S. L., Hay, L. E., Woods, R., Arnold, J. R., \& Brekke, L. D. (2016). mizuRoute version 1: a river network routing tool for a continental domain water resources applications. Geoscientific Model Development, 9(6), 2223-2238. http:/ / dx.doi.org/10.5194/gmd-9-2223-2016.

Munar, A. M., Cavalcanti, J. R., Bravo, J. M., Fan, F. M., Motta-Marques, D., \& Fragoso Junior, C. R. (2018). Coupling large-scale hydrological and hydrodynamic modeling: toward a better comprehension of watershed-shallow lake processes. Journal of Hydrology, 564, 424441. http://dx.doi.org/10.1016/j.jhydrol.2018.07.045.

Nash, J. E., \& Sutcliffe, J. V. (1970). River flow forecasting through conceptual models part I: a discussion of principles. Journal of Hydrology, 10(3), 282-290. http://dx.doi.org/10.1016/00221694(70)90255-6.

Neal, J., Schumann, G., \& Bates, P. (2012). A subgrid channel model for simulating river hydraulics and floodplain inundation over large and data sparse areas. Water Resources Research, 48(11). http://dx.doi.org/10.1029/2012WR012514.

New, M., Lister, D., Hulme, M., \& Makin, I. (2002). A high-resolution data set of surface climate over global land areas. Climate Research, 21, 1-25. http://dx.doi.org/10.3354/cr021001.

Nóbrega, M. T., Collischonn, W., Tucci, C. E. M., \& Paz, A. R. (2011). Uncertainty in climate change impacts on water resources in the Rio Grande Basin, Brazil. Hydrology and Earth System Sciences, 15(2), 585-595. http://dx.doi.org/10.5194/hess-15-585-2011.

O’Loughlin, F., Paiva, R. C. D., Durand, M., Alsdorf, D. E., \& Bates, P. D. (2016). A multi-sensor approach towards a global vegetation corrected SRTM DEM product. Remote Sensing of Environment, 182, 49-59. http://dx.doi.org/10.1016/j.rse.2016.04.018.

Paiva, R. C. D., Buarque, D. C., Collischonn, W., Bonnet, M.-P., Frappart, F., Calmant, S., \& Mendes, C. A. B. (2013). Large-scale hydrologic and hydrodynamic modeling of the Amazon River basin. Water Resources Research, 49(3), 1226-1243. http://dx.doi. org/10.1002/wrcr.20067.

Paiva, R. C. D., Collischonn, W., \& Tucci, C. E. M. (2011). Large scale hydrologic and hydrodynamic modeling using limited data and a GIS based approach. Journal of Hydrology, 406(3-4), 170-181. http://dx.doi.org/10.1016/j.jhydrol.2011.06.007.

Pappenberger, F., Beven, K. J., Hunter, N. M., Bates, P. D., Gouweleeuw, B. T., Thielen, J., \& Roo, A. P. J. (2005). Cascading model uncertainty from medium range weather forecasts (10 days) through a rainfall-runoff model to flood inundation predictions within the European Flood Forecasting System (EFFS). Hydrology and Earth System Sciences, 9(4), 381-393. http:/ /dx.doi.org/10.5194/ hess-9-381-2005.

Paz, A. R., \& Collischonn, W. (2007). River reach length and slope estimates for large-scale hydrological models based on a relatively 
high-resolution digital elevation model. Journal of Hydrology, 343(3), 127-139. http://dx.doi.org/10.1016/j.jhydrol.2007.06.006.

Paz, A. R., Collischonn, W., \& Silveira, A. L. L. (2006). Improvements in large scale drainage networks derived from digital elevation models. Water Resources Research, 42(8), W08502. http://dx.doi. org/10.1029/2005WR004544.

Paz, A. R., Collischonn, W., Bravo, J. M., Bates, P. D., \& Baugh, C. (2014). The influence of vertical water balance on modelling Pantanal (Brazil) spatio-temporal inundation dynamics. Hydrological Processes, 28(10), 3539-3553. http://dx.doi.org/10.1002/hyp.9897.

Paz, A. R., Collischonn, W., Tucci, C. E., \& Padovani, C. R. (2011). Large-scale modelling of channel flow and floodplain inundation dynamics and its application to the Pantanal (Brazil). Hydrological Processes, 25(9), 1498-1516. http://dx.doi.org/10.1002/hyp.7926.

Pedinotti, V., Boone, A., Decharme, B., Cretaux, J. F., Mognard, N., Panthou, G., Papa, F., \& Tanimoun, B. A. (2012). Evaluation of the ISBA-TRIP continental hydrologic system over the Niger basin using in situ and satellite derived datasets. Hydrology and Earth System Sciences, 16(6), 1745-1773. http://dx.doi.org/10.5194/ hess-16-1745-2012.

Planchon, O., \& Darboux, F. (2001). A fast, simple and versatile algorithm to fill the depressions of digital elevation models. Catena, 46(2-3), 159-176. http://dx.doi.org/10.1016/S03418162(01)00164-3.

Pontes, P. R. M., Fan, F. M., Fleischmann, A. S., Paiva, R. C. D., Buarque, D. C., Siqueira, V. A., Jardim, P. F., Sorribas, M. V., \& Collischonn, W. (2017). MGB-IPH model for hydrological and hydraulic simulation of large floodplain river systems coupled with open source GIS. Environmental Modelling \& Software, 94, 1-20. http://dx.doi.org/10.1016/j.envsoft.2017.03.029.

Price, R. (2018). Toward flood routing in natural rivers. Journal of Hydraulic Engineering, 144(3), 04017070. http://dx.doi.org/10.1061/ (ASCE)HY.1943-7900.0001414.

Rennó, C. D., Nobre, A. D., Cuartas, L. A., Soares, J. V., Hodnett, M. G., Tomasella, J., \& Waterloo, M. J. (2008). HAND, a new terrain descriptor using SRTM-DEM: mapping terra-firme rainforest environments in Amazonia. Remote Sensing of Environment, 112(9), 3469-3481. http://dx.doi.org/10.1016/j.rse.2008.03.018.

Saleh, F., Ducharne, A., Flipo, N., Oudin, L., \& Ledoux, E. (2013). Impact of river bed morphology on discharge and water levels simulated by a $1 \mathrm{D}$ Saint-Venant hydraulic model at regional scale. Journal of Hydrology, 476, 169-177. http://dx.doi.org/10.1016/j. jhydrol.2012.10.027.

Sampson, C. C., Smith, A., Bates, P. D., Neal, J. C., \& Trigg, M. A. (2016). Perspectives on open access high resolution digital elevation models to produce global flood hazard layers. Frontiers of Earth Science, 3. http://dx.doi.org/10.3389/feart.2015.00085.

Schumann, G. J.-P., Neal, J. C., Voisin, N., Andreadis, K. M., Pappenberger, F., Phanthuwongpakdee, N., Hall, A. C., \& Bates,
P. D. (2013). A first large scale flood inundation forecasting model. Water Resources Research, 49 (10), 6248-6257. http:/ /dx.doi. org/10.1002/wrcr.20521.

Schumann, G., Bates, P. D., Horritt, M. S., Matgen, P., \& Pappenberger, F. (2009). Progress in integration of remote sensing-derived flood extent and stage data and hydraulic models. Reviews of Geophysics, 47(4), RG4001. http://dx.doi.org/10.1029/2008RG000274.

Schwanenberg, D., Fan, F. M., Naumann, S., Kuwajima, J. I., Alvarado, R., \& Reis, A. A. (2015). Short-term reservoir optimization for flood mitigation under meteorological and hydrological forecast uncertainty. Water Resources Management, 29(5), 1635-1651. http:/ / dx.doi.org/10.1007/s11269-014-0899-1.

Seibert, J., \& McGlynn, B. L. (2007). A new triangular multiple flow direction algorithm for computing upslope areas from gridded digital elevation models. Water Resources Research, 43(4). http:/ / dx.doi.org/10.1029/2006WR005128.

Sheffield, J., Wood, E. F., Chaney, N., Guan, K., Sadri, S., Yuan, X., Olang, L., Amani, A., Ali, A., Demuth, S., \& Ogallo, L. (2014). A drought monitoring and forecasting system for sub-Sahara African water resources and food security. Bulletin of the American Meteorological Society, 95(6), 861-882. http://dx.doi.org/10.1175/ BAMS-D-12-00124.1.

Sheffield, J., Wood, E. F., Pan, M., Beck, H., Coccia, G., SerratCapdevila, A., \& Verbist, K. (2018). Satellite remote sensing for water resources management: potential for supporting sustainable development in data-poor regions. Water Resources Research, 54(12), 9724-9758. http://dx.doi.org/10.1029/2017WR022437.

Siqueira, V. A., Fleischmann, A., Jardim, P. F., Fan, F. M., \& Collischonn, W. (2016). IPH-Hydro Tools: a GIS coupled tool for watershed topology acquisition in an open-source environment. RBRH, 21(1), 274-287. http://dx.doi.org/10.21168/rbrh.v21n1. $\mathrm{p} 274-287$.

Siqueira, V. A., Paiva, R. C. D., Fleischmann, A. S., Fan, F. M., Ruhoff, A. L., Pontes, P. R. M., Paris, A., Calmant, S., \& Collischonn, W. (2018). Toward continental hydrologic-hydrodynamic modeling in South America. Hydrology and Earth System Sciences, 22(9), 48154842. http:/ /dx.doi.org/10.5194/hess-22-4815-2018.

Sorribas, M. V., Paiva, R. C. D., Melack, J. M., Bravo, J. M., Jones, C., Carvalho, L., Beighley, E., Forsberg, B., \& Costa, M. H. (2016). Projections of climate change effects on discharge and inundation in the Amazon basin. Climatic Change, 136(3-4), 555-570. http:// dx.doi.org/10.1007/s10584-016-1640-2.

Tarboton, D. G. (1997). A new method for the determination of flow directions and upslope areas in grid digital elevation models. Water Resources Research, 33(2), 309-319. http://dx.doi. org/10.1029/96WR03137.

Tavakoly, A. A., Snow, A. D., David, C. H., Follum, M. L., Maidment, D. R., \& Yang, Z.-L. (2016). Continental-Scale River Flow modeling of the Mississippi river basin using high-resolution NHDPlus 
dataset. Journal of the American Water Resources Association, 53(2), 258-279. http://dx.doi.org/10.1111/1752-1688.12456.

Tesfa, T. K., Leung, L. R., Huang, M., Li, H.-Y., Voisin, N., \& Wigmosta, M. S. (2014). Scalability of grid- and subbasin-based land surface modeling approaches for hydrologic simulations. Journal of Geophysical Research, D, Atmospheres, 119(6), 3166-3184. http://dx.doi.org/10.1002/2013JD020493.

Trigg, M. A., Wilson, M. D., Bates, P. D., Horritt, M. S., Alsdorf, D. E., Forsberg, B. R., \& Vega, M. C. (2009). Amazon flood wave hydraulics. Journal of Hydrology, 374(1), 92-105. http://dx.doi. org/10.1016/j.jhydrol.2009.06.004.

Tshimanga, R. M., \& Hughes, D. A. (2014). Basin-scale performance of a semidistributed rainfall-runoff model for hydrological predictions and water resources assessment of large rivers: the Congo River. Water Resources Research, 50(2), 1174-1188. http:/ / dx.doi.org/10.1002/2013WR014310.

Wang, L., \& Liu, H. (2006). An efficient method for identifying and filling surface depressions in digital elevation models for hydrologic analysis and modeling. International Journal of Geographical Information Science, 20(2), 193-213. http://dx.doi. org/10.1080/13658810500433453.

Wigmosta, M. S., Vail, L. W., \& Lettenmaier, D. P. (1994). A distributed hydrology-vegetation model for complex terrain. Water Resources Research, 30(6), 1665-1679. http://dx.doi.org/10.1029/94WR00436.

Wu, H., Kimball, J. S., Mantua, N., \& Stanford, J. (2011). Automated upscaling of river networks for macroscale hydrological modeling. Water Resources Research, 47(3), W03517. http://dx.doi. org/10.1029/2009WR008871.

Yamazaki, D., Almeida, G. A. M., \& Bates, P. D. (2013). Improving computational efficiency in global river models by implementing the local inertial flow equation and a vector-based river network map. Water Resources Research, 49(11), 7221-7235. http://dx.doi. org/10.1002/wrcr.20552.

Yamazaki, D., Baugh, C. A., Bates, P. D., Kanae, S., Alsdorf, D. E., \& Oki, T. (2012). Adjustment of a spaceborne DEM for use in floodplain hydrodynamic modeling. Journal of Hydrology (Amsterdam), 436-437, 81-91. http://dx.doi.org/10.1016/j.jhydrol.2012.02.045.

Yamazaki, D., Ikeshima, D., Sosa, J., Bates, P. D., Allen, G. H., \& Pavelsky, T. M. (2019). T.M. Pavelsky MERIT Hydro: A highresolution global hydrography map based on latest topography datasets. Water Resources Research, 55(6), 5053-5073. http:/ /dx.doi. org/10.1029/2019WR024873.

Yamazaki, D., Ikeshima, D., Tawatari, R., Yamaguchi, T., O’Loughlin, F., Neal, J. C., Sampson, C. C., Kanae, S., \& Bates, P. D. (2017). A high-accuracy map of global terrain elevations. Geophysical Research Letters, 44(11), 5844-5853. http://dx.doi.org/10.1002/2017GL072874.

Yamazaki, D., Kanae, S., Kim, H., \& Oki, T. (2011). A physically based description of floodplain inundation dynamics in a global river routing model. Water Resources Research, 47(4), W04501. http:/ / dx.doi.org/10.1029/2010WR009726.
Yamazaki, D., Oki, T., \& Kanae, S. (2009). Deriving a global river network map and its sub-grid topographic characteristics from a fine-resolution flow direction map. Hydrology and Earth System Sciences, 13(11), 2241-2251. http://dx.doi.org/10.5194/hess-132241-2009.

Yamazaki, D., Sato, T., Kanae, S., Hirabayashi, Y., \& Bates, P. D. (2014). Regional flood dynamics in a bifurcating mega delta simulated in a global river model. Geophysical Research Letters, 41 (9), 3127-3135. http://dx.doi.org/10.1002/2014GL059744.

Yan, K., Di Baldassare, G., Solomatine, D. P., \& Schumann, G. J.-P. (2015). A review of low-cost space-borne data for flood modelling: topography, flood extent and water level. Hydrological Processes, 29(15), 3368-3387. http://dx.doi.org/10.1002/hyp.10449.

Zhao, F., Veldkamp, T. I. E., Frieler, K., Schewe, J., Ostberg, S., Willner, S., Schauberger, B., Gosling, S. N., Schmied, H. M., Portmann, F. T., Leng, G., Huang, M., Liu, X., Tang, Q., Hanasaki, N., Biemans, H., Gerten, D., Satoh, Y., Pokhrel, Y., Stacke, T., Ciais, P., Chang, J., Ducharne, A., Guimberteau, M., Wada, Y., Kim, H., \& Yamazaki, D. (2017). The critical role of the routing scheme in simulating peak river discharge in global hydrological models. Environmental Research Letters, 12(7), 075003. http:/ /dx.doi. org/10.1088/1748-9326/aa7250.

\section{Authors contributions}

Fernando Mainardi Fan: Manuscript writing, experimental design, discussion of results.

Vinícius Alencar Siqueira: Manuscript writing, experimental design, discussion of results, model runs.

Ayan Santos Fleischmann: Manuscript writing, experimental design, discussion of results, model runs.

João Paulo Fialho Brêda: Manuscript writing, experimental design, discussion of results, model runs.

Rodrigo Cauduro Dias de Paiva: Discussion of results, manuscript review, study supervision.

Paulo Rógenes Monteiro Pontes: Discussion of results, manuscript review, study supervision.

Walter Collischonn: Discussion of results, manuscript review, study supervision.

Editor-in-Chief: Adilson Pinheiro

Associated Editor: Carlos Henrique Ribeiro Lima 